\title{
NUTRITIONAL VALUE OF GRAIN LEGUMES FOR RUMINANTS
}

\author{
R. M. DIXON AND B. J. HOSKING
}

School of Agriculture and Forestry, The University of Melbourne, Parkville, Victoria 3052, Australia

\section{CONTENTS}

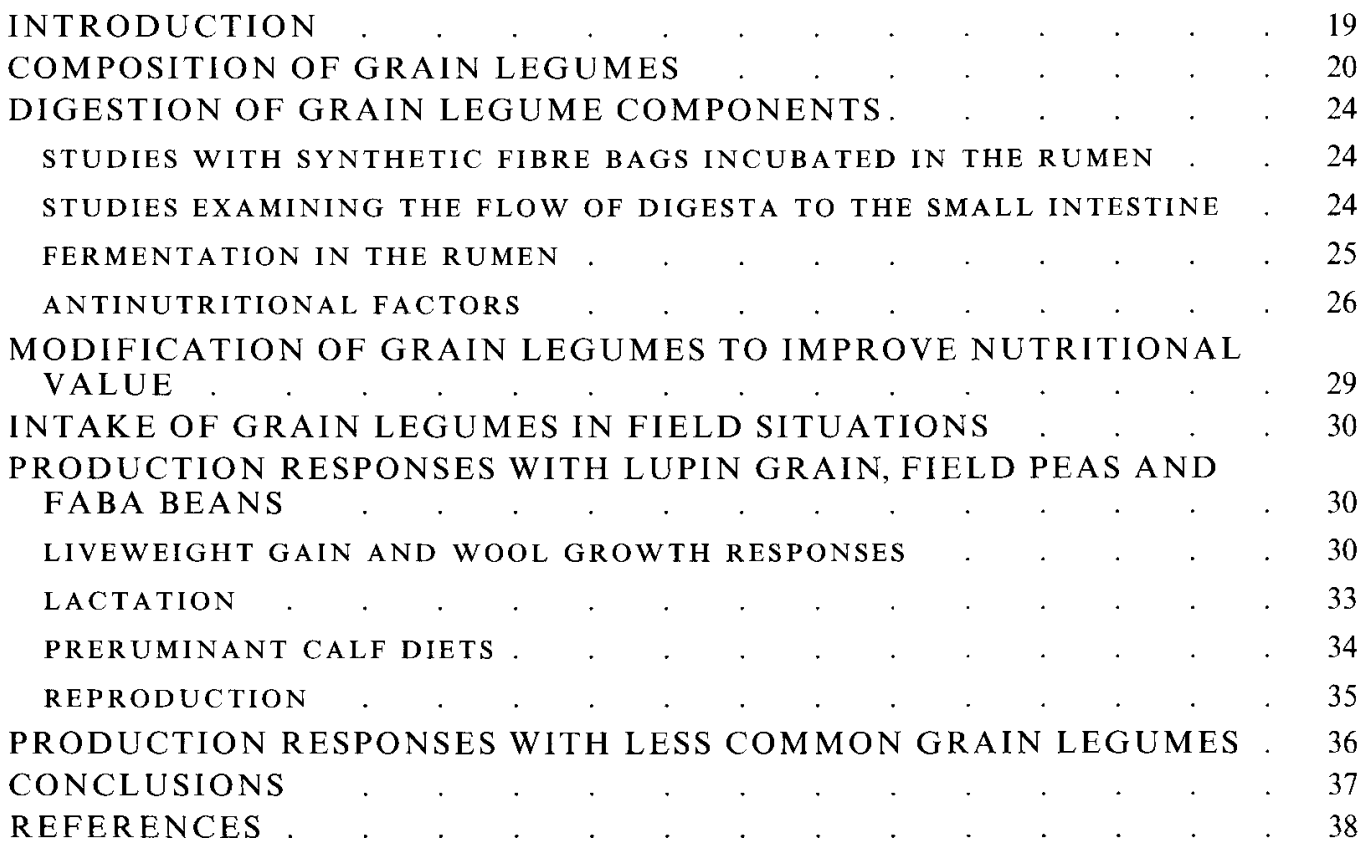

\section{INTRODUCTION}

Grain legumes or pulses have long been used as food, but during the last decade there has been an increase in interest in their role in poultry and pig diets. There has been an associated interest in the use of grain legumes, particularly field peas (Pisum sativum), lupin grain (Lupinus spp.) and faba beans (Vicia faba), in ruminant diets. As feeds high in protein, an obvious role for grain legumes is to balance other dietary ingredients low in protein. The extent to which grain legumes provide rumen degradable protein and undegraded dietary protein in various circumstances is central to their role in ruminant nutrition, and is considered in detail in this review. Most grain legumes contain an array of secondary metabolites which constitute important defences of the plant against insects and herbivores and which are resistant to gastric and intestinal digestion. These so-called antinutritional factors often have detrimental effects on mammalian digestion and metabolism. A second major aspect of this review is to consider the information available on the effects of such 
factors in the ruminant where rumen fermentation processes have the potential to modify them. Only a small number of species of grain legumes have become major crops in developed countries, and these have usually been selected as grain legumes with low to moderate levels of antinutritional factors. There are many other high-yielding grain legume species, particularly those of subtropical and tropical origin, which have traditionally been used for food and which have considerable potential to provide high protein animal feed, and to support improved animal production (National Academy of Sciences, 1979). Unfortunately they also usually contain high levels of antinutritional factors which without processing preclude their use in monogastric diets. A third purpose of this review is to consider the limitations to greater use of such grain legumes in their unprocessed form as feed for ruminant animals. Soyabean and soyabean meal will not be considered except for comparative purposes since the constraints on the use of these feedstuffs are well established.

\section{COMPOSITION OF GRAIN LEGUMES}

The chemical composition of grain legumes has been discussed in a number of review articles (Hill, 1977; Newton \& Hill, 1983; Wiseman \& Cole, 1988; Salunkhe \& Kadam, $1989 a$ ). Table 1 summarizes the composition of the range of grain legumes most likely to be used in diets for ruminants. Considerable variation may occur for each of the values given with differences between cultivars and associated with growth, harvest and storage conditions.

Crude protein content varies between species of grain legume feedstuffs from approximately $200 \mathrm{~g} / \mathrm{kg}$ dry matter (DM) for pigeon pea and chickpea to $500-550 \mathrm{~g} / \mathrm{kg}$ DM for peanut meal, soyabean meal and soyabeans. Grain legumes are usually low in the sulphur-containing amino acids (Batterham \& Egan, 1986), although, as discussed later, extensive digestion of grain legume proteins in the rumen means that in most circumstances this will be of lesser importance for ruminant diets than for monogastric diets. Although data are scarce, it appears that total sulphur content is low and nitrogen: sulphur ratio is high in grain legumes. For example for lupin grain the nitrogen:sulphur ratio is usually approximately 20:1 (Australian Feeds Information Centre, 1987; Murray et al. 1991).

In most grain legumes the principal storage polysaccharide is starch (Wiseman \& Cole, 1988; Reddy et al. 1989). For example in field peas and in faba beans starch usually constituted $300-400 \mathrm{~g} / \mathrm{kg}$ of the whole seed. However, in lupin grain the principal storage polysaccharide is $\beta$ - $(1,4)$-galactan (Hill, 1977). Appreciable amounts of $\alpha$-galactosides $(40-90 \mathrm{~g} / \mathrm{kg}$ of seed DM) are present in faba beans, peas and lupins. Fibre contents may be considered low for incorporation into ruminant diets, and of the grain legumes considered in Table 1 lupin grain had the highest crude fibre $(130 \mathrm{~g} / \mathrm{kg})$ and neutral detergent fibre $(270 \mathrm{~g} / \mathrm{kg})$ contents. Lipid content of soyabean seed and peanut seed is high, but these grain legumes are seldom fed to ruminants before oil extraction. Lupin grain contains up to $100 \mathrm{~g}$ lipid $/ \mathrm{kg}$, although Australian cultivars are more commonly in the range $50-70 \mathrm{~g} / \mathrm{kg} \mathrm{DM}$.

Most species of legume seeds contain a number of secondary metabolites which are known or suspected to have adverse effects on monogastric animals following ingestion. The role and physiological mechanisms of such antinutritional factors have been extensively investigated in monogastric animals, particularly for grain legumes such as Phaseolus vulgaris used widely as food for humans (Liener, 1980; Wiseman \& Cole, 1988; Huisman et al. 1989; Salunkhe \& Kadam, $1989 a-c$; van der Poel, 1990). Among the antinutritional factors the lectins and proteinase inhibitors are very widely distributed and are likely to be of the greatest nutritional importance in monogastric animals. Lectins constitute a class of 
Table 1. Proximate composition $(\mathrm{g} / \mathrm{kg})$ and predicted metabolizable energy content (MJ ME/kg DM) of grain legume seeds or meal

\begin{tabular}{|c|c|c|c|c|c|}
\hline & $\begin{array}{l}\text { Field pea } \\
(\text { Pisum } \\
\text { sativum })\end{array}$ & $\begin{array}{l}\text { Lupin seed } \\
\text { (Lupinus } \\
\text { spp.) }\end{array}$ & $\begin{array}{c}\text { Faba beans } \\
\text { (Vicia } \\
\text { faba) }\end{array}$ & $\begin{array}{l}\text { Chickpea } \\
\text { (Cicer } \\
\text { arietimum) }\end{array}$ & $\begin{array}{c}\text { Navy bean } \\
\text { (Phaseolus } \\
\text { vulgaris) }\end{array}$ \\
\hline Dry matter & 907 & 897 & 906 & 891 & 897 \\
\hline Crude protein $†$ & 260 & 321 & 257 & 217 & 252 \\
\hline Crude fibre $†$ & 68 & 144 & 77 & 78 & 47 \\
\hline Ether extract $\uparrow$ & 13 & 60 & 13 & 43 & 17 \\
\hline Ash $\dagger$ & 33 & 31 & 32 & 32 & 46 \\
\hline Nitrogen-free extract $\dagger$ & 633 & 447 & 626 & 619 & 636 \\
\hline \multicolumn{6}{|l|}{$\begin{array}{l}\text { Predicted metabolizable } \\
\text { energy }\end{array}$} \\
\hline Sheep & $11 \cdot 4$ & $14 \cdot 0$ & $13 \cdot 0$ & $12 \cdot 8$ & $13 \cdot 0$ \\
\hline \multirow[t]{2}{*}{ Cattle } & $12 \cdot 5$ & $14 \cdot 0$ & $14 \cdot 6$ & $13 \cdot 4$ & $12 \cdot 6$ \\
\hline & $\begin{array}{c}\text { Pigeon pea } \\
\text { (Cajanus } \\
\text { cajan })\end{array}$ & $\begin{array}{l}\text { Mung bean } \\
\text { (Vigna } \\
\text { radiata })\end{array}$ & $\begin{array}{c}\text { Peanut meal } \\
\text { (Arachis } \\
\text { hypogaea) }\end{array}$ & $\begin{array}{l}\text { Soyabean } \\
\text { seed } \\
\text { (Glycine } \\
\text { max) }\end{array}$ & $\begin{array}{c}\text { Soyabean } \\
\text { meal } \\
\text { (Glycine } \\
\text { max })\end{array}$ \\
\hline Dry matter & 888 & 898 & 915 & 909 & 891 \\
\hline Crude protein $\dagger$ & 203 & 239 & 527 & 421 & 519 \\
\hline Crude fibret & 117 & 43 & 146 & 59 & 58 \\
\hline Ether extract $\uparrow$ & 37 & 14 & 13 & 193 & 13 \\
\hline $\operatorname{Ash} \dagger$ & 50 & 41 & 50 & 54 & 66 \\
\hline Nitrogen-free extract $\dagger$ & 580 & 633 & 281 & 282 & 334 \\
\hline \multicolumn{6}{|l|}{$\begin{array}{l}\text { Predicted metabolizable } \\
\text { energy }\end{array}$} \\
\hline Sheep & $9 \cdot 9$ & $13 \cdot 0$ & $12 \cdot 8$ & $14 \cdot 0$ & $13 \cdot 3$ \\
\hline Cattle & $8 \cdot 9$ & $12 \cdot 7$ & $11 \cdot 8$ & $14 \cdot 0$ & $12 \cdot 3$ \\
\hline
\end{tabular}

$\uparrow$ DM (dry matter) basis.

Sources: Batterham \& Egan (1986); Standing Committee on Agriculture (1990).

proteins characterized by their ability to bind glycoproteins and carbohydrates, and have their principal antinutritional effect in the small intestine by interfering with the absorption of digestion end products by binding to and disrupting the epithelial cells (Jaffé, 1980; Puztai, 1989). The proteinase inhibitors of greatest importance are those which inhibit trypsin and chymotrypsin activities and hence reduce protein availability and amino acid absorption from the small intestine (Liener \& Kakade, 1980; Birk, 1989). Furthermore the sulphur amino acids of grain legume proteins are often largely present as constituents of the proteinase inhibitors; for example $30-40 \%$ of the cystine present in navy beans are constituents of proteinase inhibitors. Since the proteinase inhibitors are resistant to small intestinal digestion and also bind to and result in increased faecal excretion of proteinases (which are themselves of high sulphur-containing amino acid content), availability of sulphur-containing amino acids in grain legumes is likely to be low and secondary sulphur deficiencies may be induced. If proteinase inhibitors are of practical importance it is likely to be in dietary situations where availability of sulphur-containing amino acids is low and where requirements for sulphur-containing amino acids are high. Observations that growth of young sheep was little affected by inclusion of untreated soyabeans into feedlot diets until high levels were used suggest that soyabean proteinase inhibitors do not have major detrimental effects (Erickson \& Barton, 1987). A large number of other antinutritional 

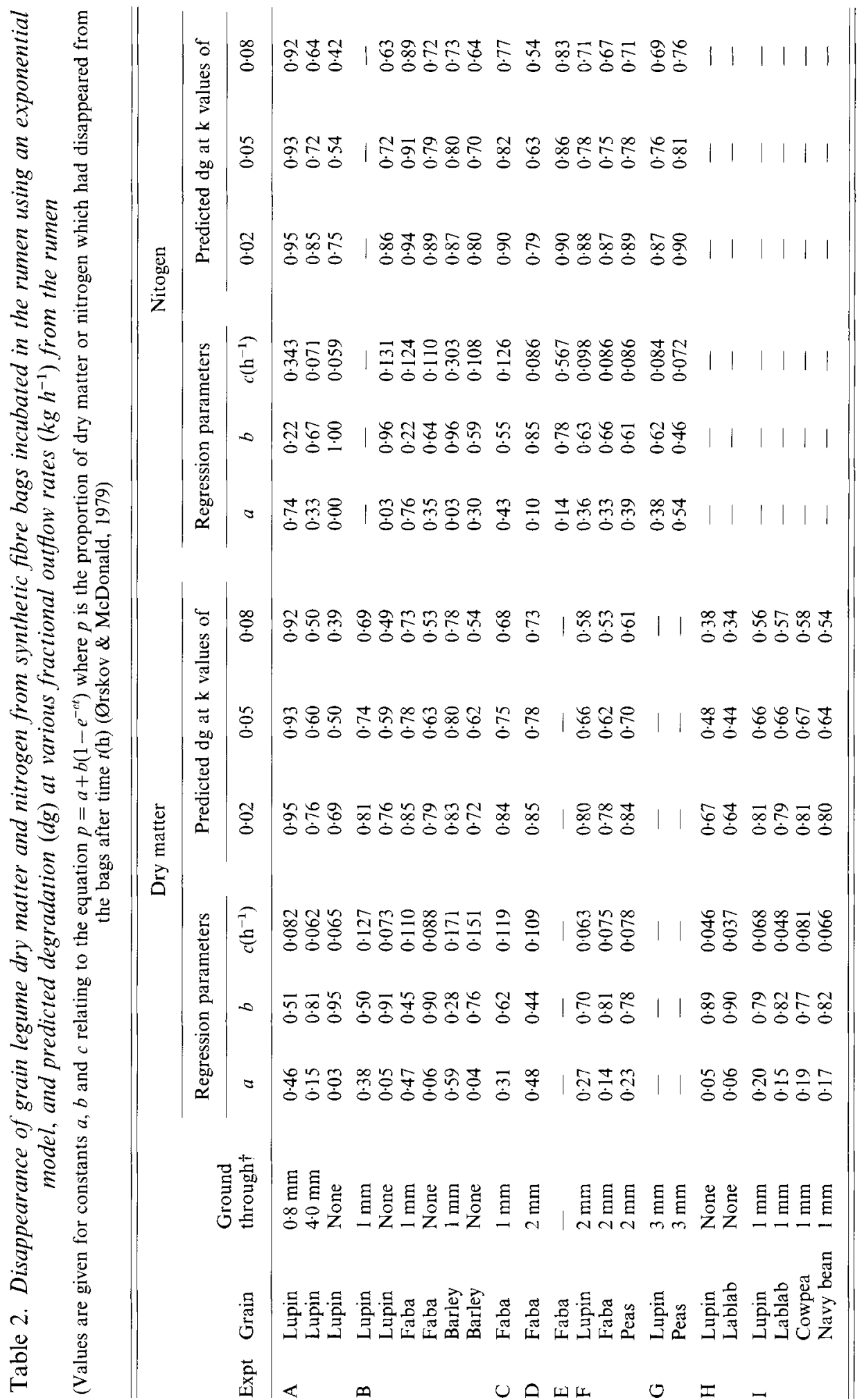

ह 톤

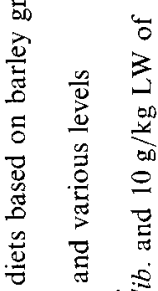
L

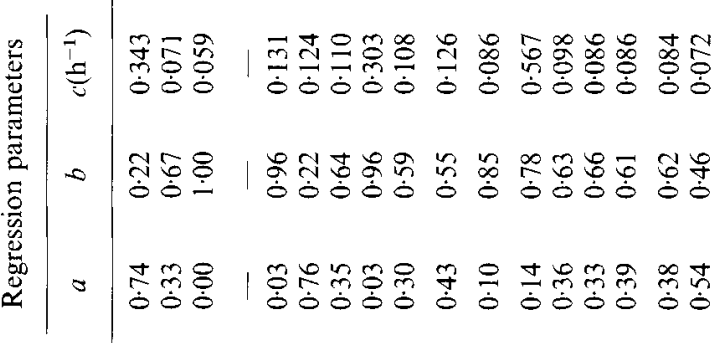

主富

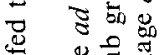

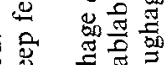

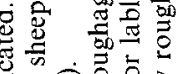
突

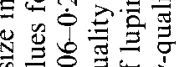

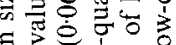

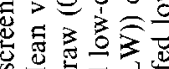

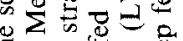
(1) कo

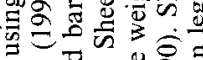

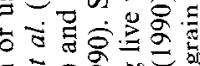

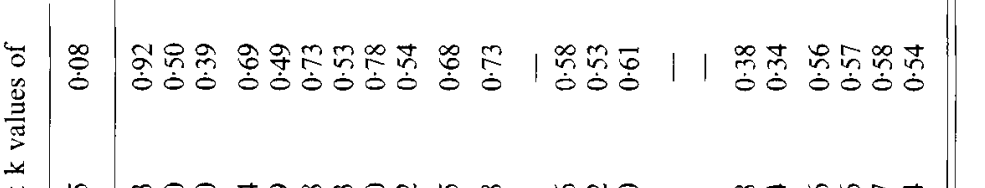
ปล

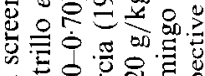

范 $\because \mathrm{s}$ 员

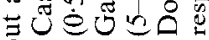
(1)

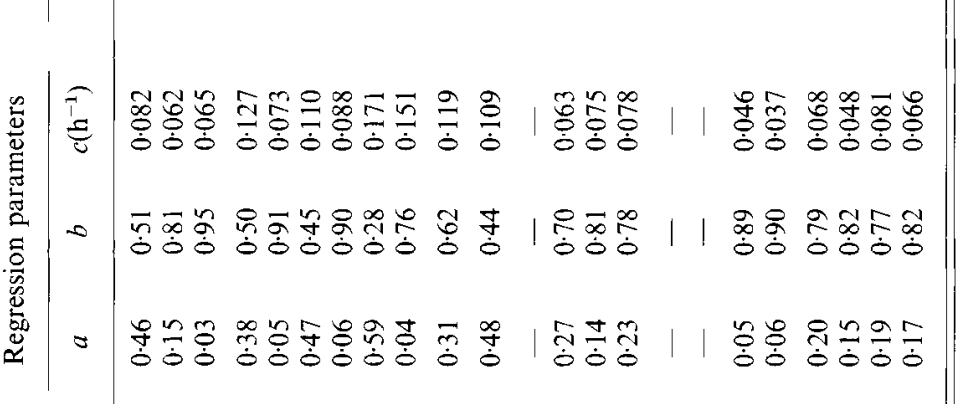

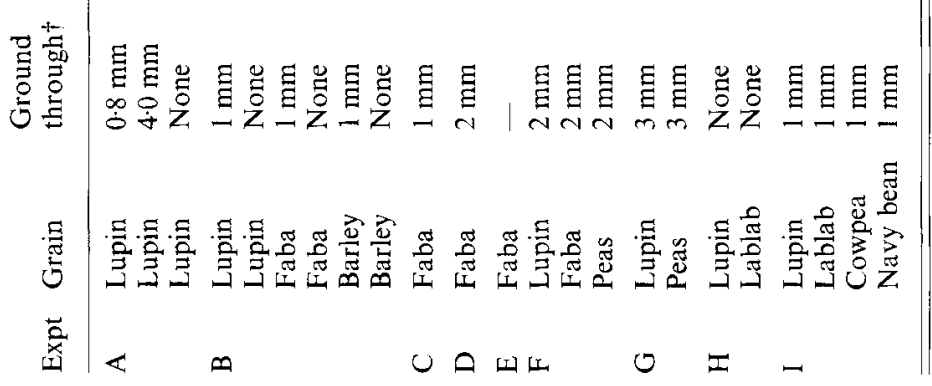
豙四 草

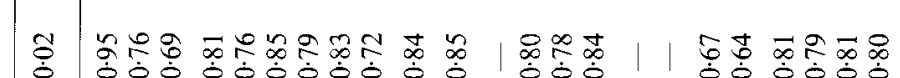

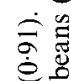
至 完 可 密尽

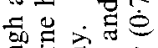

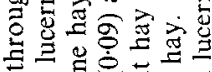

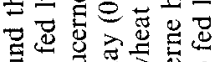
3

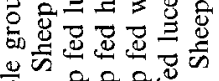

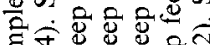

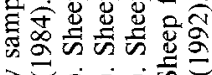
穴官穴 产 $\%$ क \% 0 on $=0000$

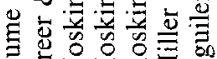

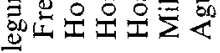

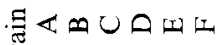
吉䒝 


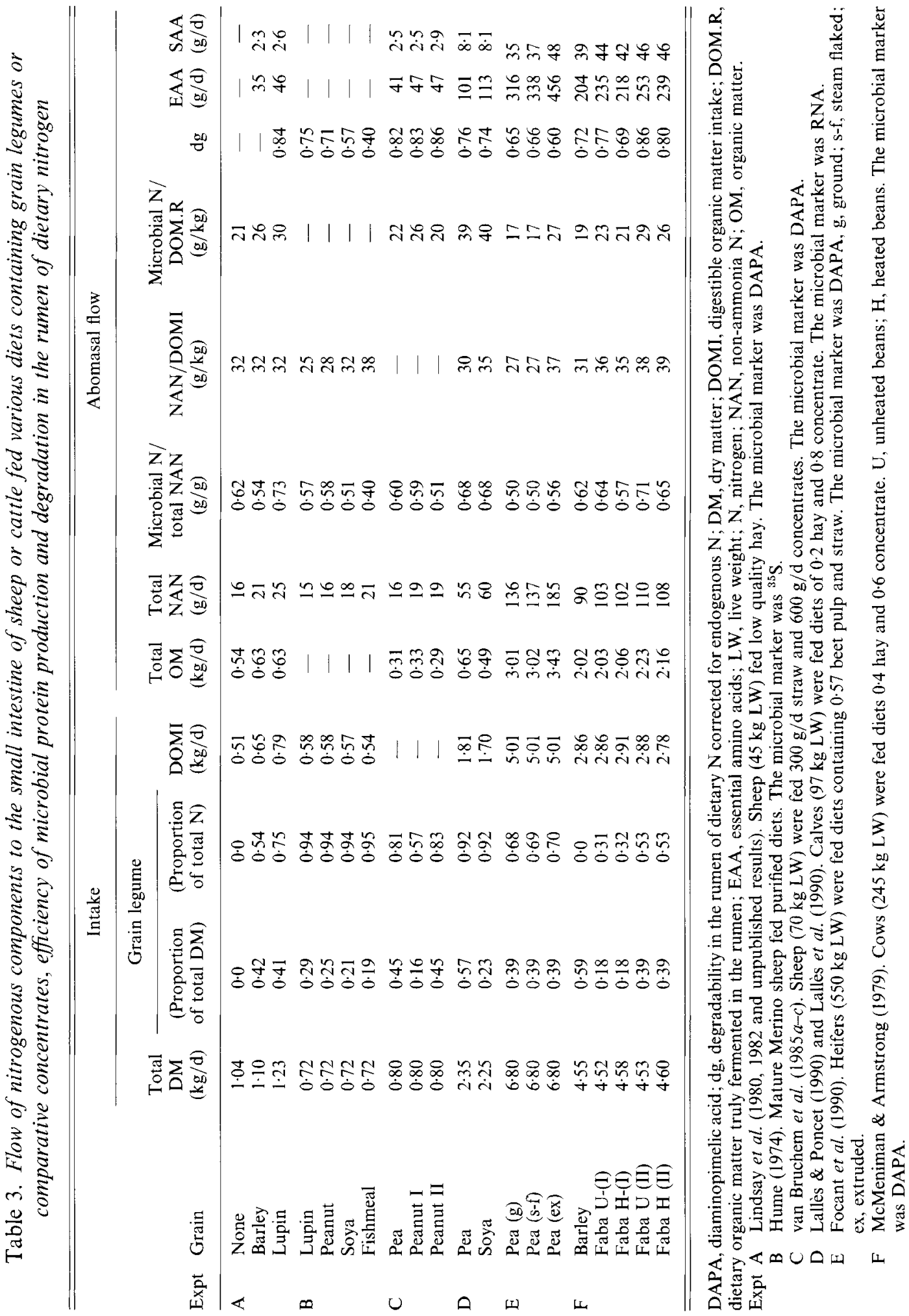


factors occur in legume seeds and some of these (tannins, non-protein amino acids, cyanogenic glucosides and alkaloids) have been identified in grain legumes (Liener, 1980).

\section{DIGESTION OF GRAIN LEGUME COMPONENTS}

\section{STUDIES WITH SYNTHETIC FIBRE BAGS INCUBATED IN THE RUMEN}

A number of experiments have measured the rate of disappearance of grain legume DM and total nitrogen (N) from synthetic fibre bags incubated in the rumen (Table 2), but these estimates of rumen fermentation of grain legume components are obviously subject to the limitations of this technique. It is evident that the method of preparation of the grain legume samples substantially affected solubilization and fermentation. For example, where the degree of processing of lupin grain was increased from 'coarse' (samples passed through a grinding mill without a screen) to 'fine' (samples ground through a $0.8 \mathrm{~mm}$ screen), solubility of DM increased from 0.03 to 0.46 and solubility of $\mathrm{N}$ from 0 to 0.74 (Freer \& Dove, 1984). In their experiment, since rate of digestion also tended to be greater for lupin grain of smaller particle size, the predicted degradability at a fractional outflow rate of $0.02 \mathrm{~h}^{-1}$ increased from 0.69 and 0.75 for $\mathrm{N}$ and DM respectively for 'coarse' samples to 0.95 for 'fine' samples. Since lupin seeds, or indeed any of the grain legume seeds under consideration, are too large to pass readily from the rumen of either sheep or cattle, it seems likely that much grain legume material of a particle size equivalent to the more coarsely ground treatments will be retained in the rumen for long periods and be fermented. Therefore on the basis of the synthetic fibre bag studies summarized in Table 2 it seems likely that, for lower rumen fractional outflow rates of the order of $0.02 \mathrm{~h}^{-1}$, at least $0.80 \mathrm{of}$ DM of lupin, pea, cowpea, navy bean and lablab grain would be fermented in the rumen. $\mathrm{N}$ of these grain legumes may be even more extensively fermented. Values for faba bean DM appear similar, but more than 0.90 of the faba bean $\mathrm{N}$ is likely to be fermented. At higher fractional outflow rates associated with higher intakes, and particularly in cattle, substantial proportions of ingested grain legumes are likely to escape fermentation and pass to the small intestine.

\section{STUDIES EXAMINING THE FLOW OF DIGESTA TO THE SMALL INTESTINE}

The limited number of experiments available where digestion has been partitioned between the rumen and the postruminal tract support the hypothesis that grain legume DM and $\mathrm{N}$ are extensively fermented in the rumen (Table 3 ). The ratio (flow of abomasal nonammonia $\mathrm{N}$ : digestible organic matter intake) was not changed by the replacement of cereal grain supplement by lupin grain supplement in the experiment of Lindsay et al. (1980), and was increased by only about $0 \cdot 15$ by the replacement of barley grain by faba beans in the experiment of McMeniman \& Armstrong (1979). This contrasts with an increase by 0.52 in this ratio when fishmeal replaced lupin grain in the experiment of Hume (1974). Increases in the flow at the abomasum of essential amino acids were similar in magnitude to those for non-ammonia $\mathrm{N}$. When grain legumes replaced cereal grains, the increases in the flow at the abomasum of sulphur-containing amino acids were small, presumably reflecting the low sulphur-containing amino acid contents of grain legume protein.

Estimates of the degradability in the rumen of dietary protein, which reflect the degradation of grain legume protein to varying extents depending on the proportion of dietary protein consisting of grain legume protein, were generally greater than 0.75 (Table 
3). This is in agreement with the estimates of degradability of grain legume protein derived from synthetic fibre bag studies discussed above. The only processing procedure which appeared to affect degradability of the grain legume protein was extrusion; degradability of field pea protein was reduced from 0.65 for ground peas to 0.60 for extruded peas (Focant et al. 1990). These degradability values are much lower than for the other experiments in Table 3, and may have been associated with factors specific to this experiment such as the use of RNA as a microbial marker and the use of mature cows. Efficiency of microbial protein production, measured as abomasal flow of microbial protein per unit of organic matter truly fermented in the rumen, appeared to be little affected by the inclusion of grain legumes in the diet.

\section{FERMENTATION IN THE RUMEN}

When lupin grain or faba beans have been fed as whole grain to sheep the majority of the seeds are likely to enter the rumen intact following the ingestion process. The proportion of seeds crushed during ingestion has been observed to vary between $0 \cdot 2$ and $0 \cdot 8$, the extent of crushing being greater for 'slow eaters' than for 'fast eaters', and for larger seeds such as faba beans than for smaller seeds such as lupin grain (Foot et al. 1983; Freer \& Dove, 1984; Hosking et al. 1985). Since negligible digestion of grain legume seeds occurs until the seed coat is disrupted by mechanical means such as rumination, presumably there may be a long delay before the grain legume components are digested. Consequently even though grain legume components are readily fermentable on exposure to rumen digesta, lags in the beginning of digestion are likely to mean that ingested supplements of whole grain legumes will be fermented over a considerable period following ingestion. This hypothesis is supported by the patterns of $\mathrm{pH}$ and ammonia concentration in rumen fluid following ingestion of lupin grain, lablab grain and sunflower meal supplement in the experiments of Egan et al. (1987) and Garcia (1990). Rumen degradable N release and carbohydrate fermentation proceeded at rates comparable with sunflower meal, and the $\mathrm{pH}$ depression was not as great as for a cereal grain supplement. Associated synthetic fibre bag measurements indicated that depression in rumen fibre digestion was greater for the cereal grain than for the lupin grain or sunflower meal supplements, although the extent to which this depression was due to rumen $\mathrm{pH}$ or to other factors such as availability of microbial substrates or the balance of microbial species present was not determined. Hynd et al. (1985) observed much greater concentrations of protozoa in the rumen when dairy cows were given lupin grain rather than barley, indicating that major changes in microbial species present in the rumen could occur when grain legume supplements replaced barley grain supplements.

In sheep fed high levels of lupin grain or wheat grain Watson et al. (1984) reported minimum rumen $\mathrm{pH}$ values of 6.0 and 5.5 respectively. Valentine \& Bartsch (1987) observed much greater depressions in rumen $\mathrm{pH}$ and rumen fibre digestion, and higher lactic acid concentrations in rumen fluid of dairy cows given barley grain than in those given equivalent amounts of lupin grain, field peas or faba beans. Since all of these grain supplements were ground the lag effects discussed above would not have occurred, suggesting that other factors such as the accessibility and characteristics of the readily fermentable carbohydrates in the various seeds were also involved in control of rumen fermentation patterns. The proportions of volatile fatty acids produced during digestion appear to be similar for grain legumes and for cereal grains. Few data are available, but no differences were observed by Hodge et al. (1984) or Valentine \& Bartsch (1987) between diets containing cereal grain and various grain legumes. 
Table 4. Disappearance of dry matter and of lectin activity (measured as haemagglutination units $(H U)$ from grain legumes incubated in nylon bags in the rumen of sheep fed roughage ad lib. and $10 \mathrm{~g} / \mathrm{kg}$ live weight of respective grain legumes (Domingo, 1990)

\begin{tabular}{|c|c|c|c|c|c|c|c|}
\hline \multirow{2}{*}{$\begin{array}{l}\text { Grain } \\
\text { legume }\end{array}$} & \multirow{2}{*}{$\begin{array}{c}\text { Initial } \\
\text { seed }\end{array}$} & \multicolumn{6}{|c|}{ Time of incubation (h) } \\
\hline & & 0 & 3 & 6 & 12 & 24 & 48 \\
\hline \multicolumn{8}{|l|}{ Dry matter ${ }^{\dagger}$} \\
\hline Navy bean & - & 0.86 & $0 \cdot 64$ & 0.58 & 0.47 & $0 \cdot 10$ & 0.01 \\
\hline Cowpea & - & 0.88 & 0.63 & 0.52 & $0 \cdot 34$ & $0 \cdot 12$ & 0.06 \\
\hline Lablab grain & - & 0.87 & $0 \cdot 67$ & 0.49 & $0 \cdot 34$ & $0 \cdot 16$ & 0.08 \\
\hline Lupin grain & - & 0.88 & 0.66 & 0.50 & 0.41 & $0 \cdot 13$ & 0.04 \\
\hline \multicolumn{8}{|l|}{ Lectin activity } \\
\hline Navy bean & 167 & 0.75 & 0.51 & $0 \cdot 38$ & $0 \cdot 14$ & 0 & 0 \\
\hline Cowpea & 21 & $0 \cdot 80$ & 0.54 & $0 \cdot 32$ & 0.03 & 0 & 0 \\
\hline Lablab grain & 23 & 0.79 & 0.61 & 0.30 & 0.04 & 0 & 0 \\
\hline Lupin grain & 14 & $0 \cdot 82$ & 0.47 & $0 \cdot 21$ & 0.09 & 0 & 0 \\
\hline
\end{tabular}

DM, dry matter.

$\uparrow$ Expressed as residual DM/g initial DM.

\pm Expressed as $\mathrm{HU} / \mathrm{mg}$ initial seed $\mathrm{DM}$, or $\mathrm{HU}$ in residue as a fraction of $\mathrm{HU}$ in original seed.

The digestibility of hulls of grain legumes appears to be much higher than for cereal grains. Edwards et al. (1973) and Rowe \& Hargreave (1988) reported digestibilities of $0.60-0.62$ for the organic matter, $\mathrm{N}$ and fibre components of faba beans and lupin grain, these values possibly reflecting the low lignin content of this material.

\section{ANTINUTRITIONAL FACTORS}

Rumen fermentation can modify many ingested antinutritional factors to forms usually less toxic to mammalian metabolism, and hence often reduce the susceptibility of ruminants to specific antinutritional factors (James et al. 1975; Hume, 1984). Ruminants are able to consume without adverse effects appreciable amounts of grain legumes such as Phaseolus, Canavalia and Lablab species known to contain high levels of antinutritional factors for rats, chickens and humans. However, lack of information on the ability of rumen fermentation to modify the antinutritional factors present in grain legumes and the consequences for digestion in the small intestine means that it is necessary to draw conclusions from the few studies in ruminants and by inference from experiments with monogastrics.

The effects of rumen fermentation on the lectin activity (measured as agglutination activity with ovine erythrocytes) of navy beans (Phaseolus vulgaris), cowpeas (Vigna unguiculata), lablab beans (Lablab purpureus) and lupin grain (Lupinus angustifolius) have been examined using the nylon bag technique (Domingo, 1990). Soaking the finely ground legumes in isotonic saline solubilized $0 \cdot 12-0 \cdot 14$ of DM and reduced by $0 \cdot 18-0 \cdot 25$ the lectin activity in the residue. Lectin activity disappeared from nylon bags at a greater rate than DM or total $N$ such that $0 \cdot 21-0 \cdot 38$ and $0 \cdot 03-0 \cdot 14$ of activity remained after 6 and 12 hours of incubation respectively (Table 4 ).

It is possible that lectins could be solubilized and disappear from nylon bags, but retain their binding activity and exert their antinutritional effects in the small intestine after passing from the rumen. In order to obtain a direct estimate of the effects of dietary lectins on absorption from the small intestine, Woldetsadick et al. (1991) measured absorption of $\mathrm{D}$-xylose from the small intestine of sheep fed a number of grain legumes. Even when grain 
Table 5. Peak D-xylose concentration in plasma $(\mathrm{mg} / \mathrm{l}) \quad 90-120 \mathrm{~min}$ after injection of $D$-xylose $(0.5 \mathrm{~g} / \mathrm{kg} \mathrm{LW})$ into the abomasum via a cannula, and recovery $(\mathrm{g} / \mathrm{g})$ of $D$-xylose in urine during the $24 \mathrm{~h}$ following injection in sheep fed $5 \mathrm{~g} / \mathrm{kg} \mathrm{LW}$ of hay and $15 \mathrm{~g} / \mathrm{kg} \mathrm{LW}$ of lucerne hay or of five grain legumes $(n=5$ or 6 ) (Woldetsadick et al. 1991)

\begin{tabular}{llc}
\hline \hline Diet & $\begin{array}{c}\text { Mean peak } \\
\text { D-xylose } \\
\text { concentration }\end{array}$ & $\begin{array}{c}\text { Recovery of } \\
\text { D-xylose in urine }\end{array}$ \\
\hline Lucerne hay & 214 & $0 \cdot 19$ \\
Navy beans & 163 & $0 \cdot 19$ \\
Lablab beans & 181 & $0 \cdot 16$ \\
Cowpeas & 219 & $0 \cdot 17$ \\
Chickpeas & 229 & $0 \cdot 22$ \\
Lupin grain & 239 & $0 \cdot 34$ \\
$\quad$ SEM & 29 & $0 \cdot 04$ \\
Significance & $\mathrm{ns}$ & $*$ \\
\hline
\end{tabular}

LW, live weight.

ns, Not significant; $* P<0 \cdot 05$.

legumes constituted approximately 0.75 of dietary DM intake, absorption of D-xylose was similar for sheep fed a lucerne diet and for grain legumes such as navy beans known to contain high levels of lectins (Table 5). These results suggest that even when high levels of Phaseolus vulgaris lectins are included in the diet of sheep and are fed as entire seed, effects of lectins on absorption from the small intestine were of minor importance. They contrast with observations of adverse effects when high levels of Phaseolus vulgaris beans were included in the diet of growing steers or of young sheep (Williams et al. 1984; Paduano et al. 1990), and may be related to differences in lectin contents and escape from the rumen of dietary constituents. Also the observation that lectins occurred in the faeces of rats consuming diets containing Phaseolus vulgaris suggests that these lectins are resistant to microbial digestion. An unexpected observation by Woldetsadick et al. (1991) was the high absorption of D-xylose from the small intestine when lupin grain was fed, suggesting a beneficial effect of lupin grain on absorption from the small intestine similar to that reported for some probiotics. In conclusion it appears that the majority of lectin activity will be inactivated by rumen fermentation, although some may well pass to the small intestine in animals with high fractional outflow rates of particulate matter from the rumen.

The effects of rumen fermentation on trypsin inhibitor activity in four grain legumes have also been examined using the nylon bag technique (Domingo, 1990). Rapid and extensive disappearance of trypsin inhibitor activity from the nylon bags occurred on exposure to rumen fermentation since only $0 \cdot 26-0.39$ and $0.05-0.06$ of original activity remained after 3 and 6 hours respectively of incubation (Table 6). However, disappearance of trypsin inhibitor activity may not be associated with hydrolysis and digestion of the proteinase inhibitors either in the rumen or postruminally. Indeed observations under in vitro conditions suggest that although the trypsin inhibitor activity of several grain legumes is rapidly solubilized in rumen fluid, inactivation of the trypsin inhibitor activity occurs slowly: after $12 \mathrm{~h}$ incubation $0 \cdot 77-1 \cdot 0$ of trypsin inhibitor activity remained, and after $24 \mathrm{~h}$ $0.0-0.37$ of trypsin inhibitor activity remained (unpublished results, C. Smith, J. H. G. Holmes and R. M. Dixon). Furthermore, the observation that high levels of supplementary cowpeas, which contain much of their sulphur amino acids as constituents of proteinase inhibitors, increased liveweight gain but not wool growth of Merino sheep (Paduano et al. 1990) suggests low availability of cowpea sulphur amino acids in the small intestine. 
Table 6. Disappearance of dry matter $(D M)$ and trypsin inhibitor activity (measured as trypsin units inhibited (TUI)) from nylon bags incubated in the rumen of sheep fed roughage ad lib. and $10 \mathrm{~g} / \mathrm{kg}$ live weight of respective grain legumes (Domingo, 1990)

\begin{tabular}{lcccc}
\hline & \multicolumn{4}{c}{ Grain legume } \\
\cline { 2 - 4 } Measurement & Navy bean & Cowpea & Lablab & Lupin \\
\hline Trypsin inhibitor activity in original beans & 3.22 & 2.59 & 1.58 & 0.95 \\
(TUI/mg DM) & & & & \\
DM remaining at $3 \mathrm{~h} \dagger$ & 0.64 & 0.63 & 0.67 & 0.66 \\
Trypsin inhibitor remaining at $3 \mathrm{~h} \ddagger$ & 0.26 & 0.26 & 0.39 & 0.37 \\
DM remaining at $6 \mathrm{~h} \dagger$ & 0.58 & 0.52 & 0.49 & 0.50 \\
Trypsin inhibitor remaining at $6 \mathrm{~h} \ddagger$ & 0.05 & 0.06 & 0.06 & 0.05 \\
\hline
\end{tabular}

$\uparrow$ Residual DM/g original DM.

$\ddagger$ Residual TUI/original TUI.

Tannins may complex with proteins in the rumen, and by binding with feed proteins and microbial enzyme systems reduce rumen microbial activity and digestion of dietary substrates (Mangan, 1988). Among the grain legumes faba beans contain high levels of condensed tannins. With faba bean cultivars containing $60-80 \mathrm{~g} \operatorname{tannin} / \mathrm{kg}$ whole seed, in vitro digestibility of bean testa was only $0 \cdot 3-0 \cdot 5$ of that of the testa of tannin-free cultivars. Since the testa constituted only a fraction of whole seed, the digestibility of whole seed DM and $\mathrm{N}$ of high tannin cultivars were 0.9 and 0.7 respectively of that of tannin-free cultivars (Griffiths \& Jones, 1977; Buckley et al. 1983). For forages of Lotus species the reduction in rumen digestion has been linearly related to tannin content. More importantly, in the range $0-100 \mathrm{~g}$ total condensed tannin per $\mathrm{kg}$ feed DM, Lotus tannins in the diet substantially increased flow of protein to and absorption of amino acids from the small intestine (Barry et al. 1986). The effects of tannins of different plant species can vary widely (Mangan, 1988), so extrapolation from results with Lotus species forage to grain legumes must be made with caution. If total condensed tannin contents of grain legumes range up to $20 \mathrm{~g} / \mathrm{kg}$ (Jadhav et al. 1989), and the grain legumes are used as minority components of the diet, it appears likely that tannins in grain legumes will have only a minor effect on digestion of roughage in the rumen and protein flow to the small intestine. Nevertheless it is possible that locally high tannin concentrations could occur around grain legume seeds during rumen digestion to reduce the rate of rumen digestion of the protein and carbohydrate components of the grain legume and enhance their availability for digestion in the small intestine.

There appears to be little information on the effects and the metabolism in the rumen of non-protein amino acids other than mimosine (Jones, 1985). Most amino acids are rapidly degraded in the rumen by the action of bacterial deaminases. However, the non-protein amino acids are known to have toxic effects on micro-organisms (Fowden et al. 1967), and hence presumably on rumen microbes. Canavanine and extracts of Canavalia ensiformis seed known to contain a number of antinutritional factors including canavanine reduced microbial growth and digestion of fibre in a rumen fluid in vitro system (Mora et al. 1980, 1981). Inclusion of Canavalia ensiformis seed in the diet of sheep reduced the rate of rumen fermentation of plant material, particularly of the more fibrous components (Dixon et al. 1983). The appearance of canavanine in rumen fluid of sheep following administration of ground Canavalia seed directly into the rumen was examined by Mora et al. (1989). Following a peak concentration after 3-6 h, canavanine concentration declined at a rate 
which indicated that some metabolism occurred in the rumen but at a much slower rate than with protein amino acids.

Information on the ability of rumen fermentation to modify other antinutritional factors in grain legumes appears to be lacking. Given the amounts of antinutritional factors ingested from grain legumes commonly utilized as food following cooking, and the potential for modification in the rumen, adverse effects appear unlikely. An exception to this generalization may occur with alkaloids such as those found in some non-selected species of Lupinus which are known to be toxic to ruminants (Cheeke, 1989).

\section{MODIFICATION OF GRAIN LEGUMES TO IMPROVE NUTRITIONAL VALUE}

It appears that, as with cereal grains, grain legumes should be ground or rolled before feeding to cattle. When lupin grain was fed as whole seed to cattle, an appreciable proportion (up to 0.26 in dairy cattle) escaped digestion and was excreted in faeces (May \& Barker, 1984; Valentine \& Bartsch, 1986). The observation of the latter authors that the decrease in digestibility could be attributed entirely to the whole grain recovered in faeces suggests that the grain need only be cracked to allow complete digestion by cattle. As for cereal grains, it appears unnecessary to process grain legumes for sheep.

The extensive fermentation of grain legume protein in the rumen has led to investigations into means to protect grain legume protein against fermentation and thus increase the undegraded dietary protein component. A number of experiments have shown that formaldehyde treatment can reduce rate of digestion in nylon bags and reduce solubility in vitro of $\mathrm{N}$ in faba beans, lupin grain and Canavalia grain. In growth trials with young sheep or cattle and in a lactation trial no significant positive responses were observed due to formaldehyde treatment of faba beans (Sharma \& Nicholson, 1975) or lupin grain (Fortune et al. 1980; Hynd \& Allden, 1986; Davis et al. 1987; Hough, 1991). This suggests that it is difficult to increase effectively the supply of absorbed amino acids from grain legume protein with formaldehyde treatment or that an increased amino acid supply is associated with low availability of some essential amino acids (Ashes et al. 1984). Dry heat treatment reduced the solubility of faba bean protein in rumen fluid, but did not change the proportion of the protein escaping rumen fermentation in cattle (McMeniman \& Armstrong, 1979). Autoclaving reduced the solubility and the rate of rumen fermentation of both DM and N components of lupin grain, pea grain and faba beans (Aguilera et al. 1992). Extrusion of field peas reduced rumen degradability of the pea protein from 0.65 to 0.60 in cattle (Table 3), demonstrating that this manipulation has some potential. However, Hough (1991) observed that extrusion of lupin grain had no effect on intake, liveweight (LW) gain or wool growth of sheep. Sharma \& Nicholson (1975) treated faba beans with a mixture of acetic and propionic acids, and reported substantial increases in the protein digested in the small intestine and in nitrogen balance. We are not aware of any production trials with grain legumes treated in this manner. Consideration must also be given to the possibility that effective protection against rumen fermentation of grain legumes which contain high levels of antinutritional factors may be counterproductive if the passage of antinutritional factors to the small intestine is also increased.

The high N:S ratio and low sulphur amino acid content of lupin grain has led to several experiments to examine the consequences of addition of inorganic sulphur to reduce this ratio to the range $(10-15: 1)$ required for maximum microbial protein synthesis. The results observed have varied. Peter et al. (1987) observed increased LW and wool growth in young sheep on addition of gypsum to lupin grain supplements, but equivalent responses occurred to gypsum supplements in the absence of lupins. Conversely Hough (1991) found no effect 
of gypsum supplements in the presence or absence of lupin grain supplements on growth of dairy heifers, while Murray et al. (1991) observed a response to gypsum when the basal diet was low in total sulphur. It appears that responses are likely to occur to fortification of lupin grain supplements with inorganic sulphur only if the basal diet is deficient in total sulphur. With some other grain legumes where availability of the sulphur is low due to proteinase inhibitors, provision of additional sulphur may be more important. Methionine and Mepron, a form of methionine protected against rumen fermentation, have been examined as additives for lupin supplements in dairy cows (Hough, 1991) and sheep (Murray et al. 1991), but neither was effective in increasing milk or wool production.

\section{INTAKE OF GRAIN LEGUMES IN FIELD SITUATIONS}

Experience with feeding lupin grain and field peas suggests that both of these grain legumes are usually readily acceptable by sheep and cattle. From a series of preference trials Hutson \& van Mourik (1981) concluded that, for a wide range of feeds offered, whole grain peas, lupin grain and cereal grains were among those most highly preferred, but preference was low for faba beans. Some other grain legumes such as Canavalia and lablab beans have not been readily accepted by sheep, goats or cattle (Addison et al. 1984; Paredes \& Escobar, 1984; Paredes et al. 1987; Ismartoyo, 1989; Troccoli et al. 1989), possibly because of the antinutritional factors present in these grain legumes.

Sheep are able to consume virtually all lupin and faba bean seed spilt on the ground at harvest or due to pod shattering. Cattle apparently have this ability for faba beans but not for lupins, presumably because of their larger buccal parts (Carbon et al. 1972; Allden \& Geytenbeek, 1984). This characteristic is utilized in Australia in low labour management procedures to provide restricted amounts of lupin grain supplements with satisfactory distribution among individual sheep in the flock. Commonly, lupin grain is distributed using a fertilizer spreader at intervals of up to a month, and intake of the grain by individual sheep in the flock is limited by their ability to find and consume the individual seeds (Rowe \& Ferguson, 1986; Morcombe et al. 1988; Curtis \& Mavrantonis, 1990).

\section{PRODUCTION RESPONSES WITH LUPIN GRAIN, FIELD PEAS AND FABA BEANS}

\section{LIVEWEIGHT GAIN AND WOOL GROWTH RESPONSES}

Numerous experiments in Australia have examined responses in LW change and wool growth to a grain legume, usually lupin grain, fed as a supplement to roughage diets for sheep. When lupin grain has been fed as a supplement with low to medium quality roughage, $\mathrm{LW}$ change responses have usually been linear for levels of supplement up to at least $15 \mathrm{~g} / \mathrm{kg} \mathrm{LW}$ (Fig. 1).

Responses to grain legume supplements appear to be inversely related to the rate of LW change of animals fed the unsupplemented roughage, and hence the quality of the basal roughage. Efficiency of utilization of grain legume supplements to reduce $\mathrm{LW}$ loss ranged from approximately $0.8 \mathrm{~g} \mathrm{LW}$ change/g grain legume DM for very low quality roughages where sheep were losing LW rapidly to an efficiency of approximately $0 \cdot 2-0 \cdot 3 \mathrm{~g} \mathrm{LW}$ gain $/ \mathrm{g}$ grain legume DM for medium quality roughages where sheep were in maintenance or slow growth (Fig. 2). The higher efficiency associated with the lower quality roughages may have been associated with factors such as provision of rumen degradable protein for low $\mathrm{N}$ roughages, differences in composition of $\mathbf{L W}$ change and lower maintenance energy requirements of sheep during prolonged undernutrition. 


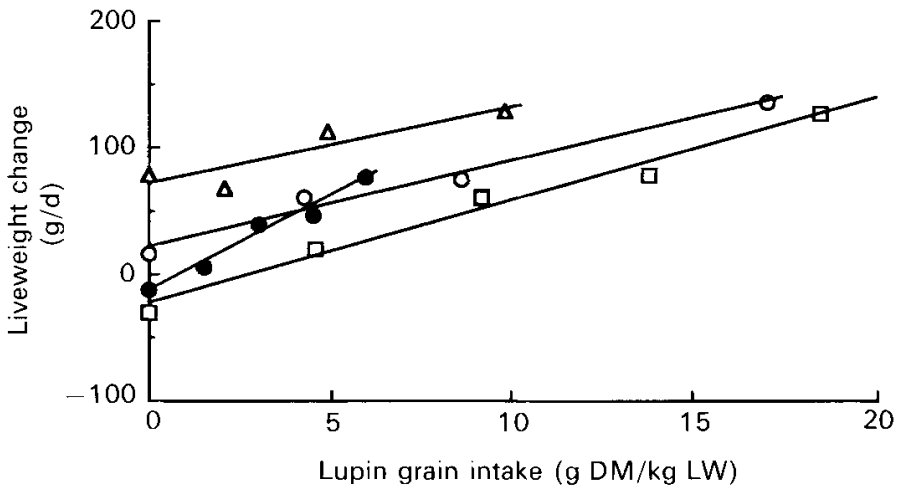

Fig. 1. The relationships between the amounts of lupin grain supplements fed and the liveweight change of young sheep in the experiments of Paduano et al. (1990) (O), Hough (1991) (O), R. M. Dixon (unpublished results) $(\triangle)$ and Rowe et al. (1989) ( $\square$ ). Mean live weights of the sheep at the beginning of supplementation ranged from 22 to $30 \mathrm{~kg}$.

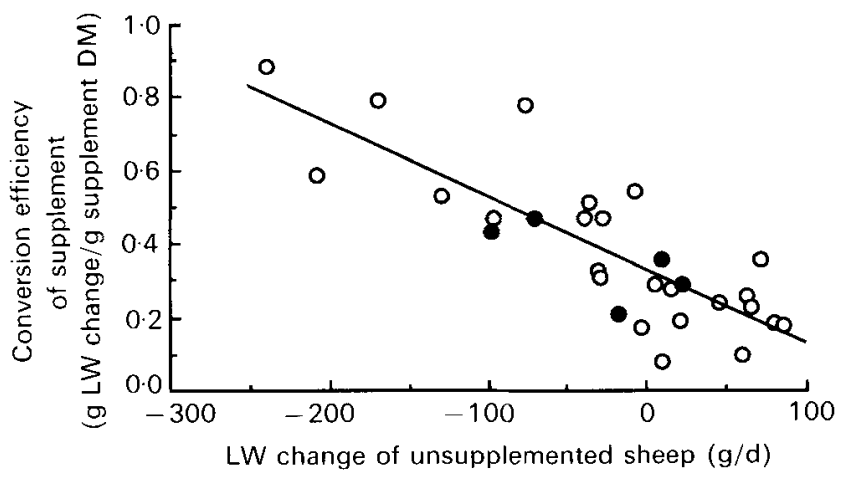

Fig. 2. The relationship between the rate of liveweight (LW) change of unsupplemented sheep consuming roughage and the efficiency of conversion of lupin grain $(O)$ or field pea $(O)$ supplements fed at levels up to $15 \mathrm{~g} / \mathrm{kg} \mathrm{LW}$. The equation of the regression line is $y=0.33-0.0020 \times\left(R^{2}=0.67\right)$. Data are from the experiments of Allden (1969), Arnold \& Wallace (1977), Butler (1981), Valentine \& Wickes (1981), Foot et al. (1983), Hodge \& Bogdanovic (1983), Aitchison et al. (1986), Hynd \& Allden (1986), Rowe \& Ferguson (1986), Smith \& Warren (1986a,b), Aitchison et al. (1988), Rowe et al. (1989), Garcia (1990), Morcombe \& Ferguson (1990), Paduano et al. (1990), Thompson \& Curtis (1990), Hough (1991), Pomares (1991), S. H. Bird and M. Dicko, unpublished results, R. M. Dixon and B. J. Hosking, unpublished results. DM, dry matter.

A few experiments have compared production responses among grain legumes. Foot et al. (1983) observed similar responses to lupin grain and soyabean meal in young sheep grazing partly senesced summer pasture. In a number of production trials with sheep or cattle grazing cereal stubble or low quality pasture, pea or faba bean supplements tended to result in lower LW change responses than lupin grain supplements (Allden \& Geytenbeek, $1980 a, b$; Hawthorne, 1980; Hynd \& Allden, 1986; Morcombe \& Ferguson, 1990). These differences may have been due principally to the higher metabolizable energy and total $\mathrm{N}$ contents of lupin grain.

Cereal grain supplements have usually, but not invariably, given lower LW gain responses than equivalent amounts of legume grain (Kenney, 1981; Rowe et al. 1989; Morcombe \& Ferguson, 1990). When comparisons have been made between lupins and barley fortified with non-protein $\mathrm{N}$ and inorganic sulphur for sheep fed wheat straw 
Table 7. Results of experiments where young castrate sheep have been fed medium quality roughage and supplements of lupin grain, barley grain, cottonseed meal or fishmeal $(R . M$. Dixon and B.J. Hosking, unpublished results)

(In all experiments roughage was fed ad lib. and supplement was fed twice weekly. Intake of metabolizable energy (ME) was estimated from measurements of intake and excretion of faeces. Wool growth was measured by clipping midside patches, and is expressed as $\mathrm{mg}$ greasy wool grown per $100 \mathrm{~mm} \times 100 \mathrm{~mm}$ patch per day)

\begin{tabular}{|c|c|c|c|c|c|c|c|}
\hline \multirow[b]{2}{*}{ Expt } & \multirow[b]{2}{*}{ Diet } & \multicolumn{3}{|c|}{ Dry matter intake $(\mathrm{g} / \mathrm{d})$} & \multirow{2}{*}{$\begin{array}{l}\text { ME intake } \\
(\mathrm{MJ} / \mathrm{d})\end{array}$} & \multirow{2}{*}{$\begin{array}{c}\text { LW } \\
\text { gain }(g / d)\end{array}$} & \multirow{2}{*}{$\begin{array}{c}\text { Wool } \\
(\mathrm{mg} / \text { patch daily) }\end{array}$} \\
\hline & & Roughage & Supplement & Total & & & \\
\hline \multirow[t]{4}{*}{ A } & Control & 1040 & 0 & 1040 & $9 \cdot 0$ & 5 & 132 \\
\hline & Barley + urea $+S$ & 883 & 174 & 1057 & $9 \cdot 3$ & 19 & 121 \\
\hline & Lupin & 905 & 178 & 1083 & $10 \cdot 0$ & 56 & 146 \\
\hline & SEM & 37 & - & 37 & $0 \cdot 13$ & 13 & 6 \\
\hline \multirow[t]{4}{*}{ B } & Control & 997 & 0 & 997 & $9 \cdot 1$ & 72 & 145 \\
\hline & Barley + urea $+S$ & 844 & 175 & 1019 & $9 \cdot 2$ & 14 & 154 \\
\hline & Lupin & 944 & 178 & 1122 & $9 \cdot 5$ & 136 & 159 \\
\hline & SEM & 36 & - & 36 & $0 \cdot 15$ & 11 & 12 \\
\hline \multirow[t]{4}{*}{$\mathrm{C}$} & Control & 950 & 0 & 950 & 一 & 75 & 130 \\
\hline & Barley & 775 & 218 & 993 & - & 85 & 142 \\
\hline & Lupin & 741 & 221 & 962 & - & 114 & 137 \\
\hline & SEM & 18 & 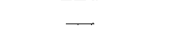 & 18 & - & 4 & 7 \\
\hline \multirow[t]{6}{*}{$\mathrm{D}$} & Control & 724 & 0 & 724 & $5 \cdot 5$ & 46 & 87 \\
\hline & Barley + urea $+S$ & 586 & 251 & 837 & $7 \cdot 3$ & 103 & 114 \\
\hline & Lupin & 537 & 237 & 774 & $7 \cdot 1$ & 98 & 128 \\
\hline & Cottonseed meal & 696 & 148 & 844 & $6 \cdot 8$ & 96 & 128 \\
\hline & Fishmeal & 795 & 97 & 892 & $7 \cdot 6$ & 126 & 147 \\
\hline & SEM & 21 & - & 21 & $0 \cdot 18$ & 8 & 8 \\
\hline \multirow[t]{6}{*}{$\mathrm{E}$} & Control & 883 & 0 & 883 & $7 \cdot 1$ & 78 & 98 \\
\hline & Barley + urea $+S$ & 747 & 231 & 978 & $8 \cdot 3$ & 131 & 106 \\
\hline & Lupin & 686 & 233 & 919 & $8 \cdot 5$ & 128 & 130 \\
\hline & Cottonseed meal & 815 & 157 & 972 & $7 \cdot 7$ & 114 & 120 \\
\hline & Fishmeal & 811 & 105 & 916 & $8 \cdot 1$ & 143 & 141 \\
\hline & SEM & 36 & - & 36 & $0 \cdot 31$ & 10 & 9 \\
\hline
\end{tabular}

LW, live weight.

Experiment A Merino sheep (initially approximately $36 \mathrm{~kg} \mathrm{LW}$ and $12-15$ months of age) fed in individual pens or metabolism crates for 6 weeks. The basal diet consisted of oaten hay $(n=6)$.

Experiment B As for Experiment A except that initial LW of the sheep was approximately $41 \mathrm{~kg}$, and for the barley + urea $+S$ treatment the urea and $S$ were mixed with the roughage rather than the supplement.

Experiment C Merino lambs (initially approximately $28 \mathrm{~kg} \mathrm{LW}$ and 8 months of age) were fed in group pens ( 3 pens each containing 5 sheep per treatment) for 10 weeks. The basal diet consisted of 0.8 oat hay and $0 \cdot 2$ lucerne hay.

Experiment D Border Leicester $\times$ Merino cross lambs (initially approximately $25 \mathrm{~kg} \mathrm{LW}$ and 6 months of age) fed in individual pens for 10 weeks. The basal diet consisted of 0.83 oat hay plus 0.17 lucerne hay $(n=8-10)$.

Experiment E As for Experiment D $(n=6-9)$.

(Valentine \& Wickes, 1981) or medium quality roughage (Table 7), although lupin grain often results in higher intake, LW change and wool growth than the cereal grain supplement, the increases were small compared with those obtained with fishmeal supplements. This suggests that where greater responses to grain legume than to cereal grain supplements have been observed, they have been principally associated with provision of $\mathrm{N}$ as a microbial substrate, although in some experiments other factors such 
as provision of some undegraded dietary protein, a higher metabolizable energy content of the grain legume and greater reduction of rumen fibre digestion by cereal starch than by grain legume carbohydrates may also have been involved. When LW change responses have been greater with a grain legume than a cereal grain, roughage intake has also been substantially higher in the presence of the grain legume supplement (Hodge \& Bogdanovic, 1983; Smith \& Warren, 1986a,b; Godfrey et al. 1990).

Lupin grain has been compared with high-protein supplements such as oilseed meals, meatmeal and fishmeal. In a series of experiments Smith \& Warren $(1986 a, b)$ compared lupin grain with pelleted cottonseed meal of low rumen solubility as supplements for growing sheep and cattle fed poor quality roughage. Replacement of lupin grain by pelleted cottonseed meal supplement increased efficiency of conversion of supplement $\mathrm{N}$ from 15 to $32 \mathrm{~g} \mathrm{LW}$ change/g supplement $\mathrm{N}$ in one experiment with young sheep, and from 7.9 to $10 \cdot 1 \mathrm{~g} \mathrm{LW}$ change/g supplement $\mathrm{N}$ in a second experiment with growing cattle. However, in a third experiment efficiency of supplement $\mathrm{N}$ utilization as $\mathrm{g}$ LW change/g supplement $\mathrm{N}$ was not changed. With sheep fed medium quality roughage (Table 7 ), feed intake and LW gain of young sheep were increased substantially by replacement of lupin grain with an isonitrogenous amount of fishmeal, but increases were not observed with sunflower or with cottonseed meal until very high levels were fed. Similarly Egan et al. (1987) reported similar LW gains for lupin and sunflower meal supplements for lambs grazing low quality pasture. Hence supplements high in undegraded dietary protein have resulted in greater growth responses than lupin grain in some, but not all, experimental situations.

Increases in wool growth in Merino sheep have often, but not invariably, been observed in response to lupin grain or field pea supplements. The responses measured during the period of supplementation or at subsequent shearing have usually been similar to, or only slightly greater than, those observed with equivalent amounts of cereal grain supplement (Kenney, 1981; Valentine \& Wickes, 1981; Foot et al. 1983; Rowe et al. 1989; Morcombe \& Ferguson, 1990; Table 7). In Merino sheep fed roughage diets, wool growth is responsive to supply of amino acids, particularly sulphur-containing amino acids. Poor responses as wool growth are consistent with the evidence that little grain legume protein escapes rumen fermentation, and that which does escape has a low content of sulphur-containing amino acids. Tensile strength of wool, an important parameter of wool quality which often declines to unsatisfactory strengths in sheep fed low quality roughage, has been increased by low levels of supplementation, but the improvement in tensile strength was similar for lupin grain and equivalent amounts of cereal grains (Rowe et al. 1989; Thompson \& Curtis, 1990).

Grain legumes have been incorporated into high-grain diets for early weaned lambs, growing sheep and pregnant and lactating ewes fed for production, or fed at restricted levels for survival during drought or for superfine wool production (Hodge et al. 1981; Kenney \& Smith, 1985; Kenny, 1986; Cottle, 1988). Replacement of cereal grain by grain legumes has generally increased intake, LW gain, wool growth and feed conversion, but it appears that these increases can be explained satisfactorily by the high metabolizable energy and $\mathrm{N}$ contents of grain legumes.

\section{LACTATION}

Grain legumes have been examined as supplements for lactating dairy cows fed diets based on medium quality roughage during seasonal scarcity of high quality pasture. In cows producing up to $25 \mathrm{lmilk}$ per day lupin grain appears to be a very satisfactory supplement and usually gave better production responses than barley grain and non-protein nitrogen mixtures (Bartsch et al. 1986; Valentine \& Bartsch, 1990; Hough, 1991). The responses with 
peas and faba beans were not as great as with lupin grain, particularly in maintaining milk fat content. Comparisons between faba beans and soyabean meal in dairy concentrate concluded that there was no difference in milk production, and in one experiment milk fat was higher with the faba beans due, probably, to the fibre content of the latter (Ingalls \& McKirdy, 1974; Ingalls et al. 1980). It is not clear why milk fat content seems to be maintained at a higher level with lupin than barley grain as reported by Bartsch et al. (1986) and Valentine \& Bartsch (1990). The high level of digestible fibre in the lupin grain could contribute to maintenance of a favourable acetate:propionate ratio in the rumen. However, in the only experiment of which we are aware where rumen acetate:propionate ratios have been measured in lactating dairy cows, no differences were found between the grain legume and barley supplements (Valentine \& Bartsch, 1987). In dry sheep, acetate: propionate ratios were similar for diets based on wheat grain or lupin grain (Hodge et al. 1984) or when high levels of lupin supplement were added to a basal roughage/oat grain diet (Teleni et al. 1989). Possibly a slow rate of digestion and the high lipid content of lupins contributes to maintaining milk fat. Hadsell \& Sommerfeldt (1988) suggested that increased milk production and milk fat content when the grain legume chickpeas (Cicer arietinum) replaced a soya-maize concentrate was due to the high lipid content of the chickpeas.

With cows fed high quality pasture, lactational responses to lupin grain have been similar to those for oat or barley grain (Moate et al. 1984; Valentine \& Bartsch, 1989; Hough, 1991). With diets based on maize silage, intakes and milk production were substantially lower with rolled lupin grain than with protein sources likely to provide considerable amounts of undegraded dietary protein (Lemerle et al. 1985), supporting the hypothesis that lupin grain provides little undegraded dietary protein.

\section{PRERUMINANT CALF DIETS}

Peas and faba beans have been examined as sources of protein for preruminant calves. Bell et al. $(1974,1979)$ showed that the digestibility of both DM and protein in peas was low in calves, particularly those less than 14 days of age. Pea protein concentrate and pea protein isolate which contained pea protein but less of the pea starch or oligosaccharides were more digestible than the original peas, but it was not clear to what extent the improvement in digestibility was associated with the elimination of the carbohydrate fractions or with a decrease in the ratio of albumin: globulin proteins (Bhatty $\&$ Christison, 1980). It appears that with methionine addition to the diet, pea protein concentrate could provide up to about $30 \%$ of dietary protein without adverse effects on calf growth, but that higher levels were associated with substantial reductions in growth (Bell et al. 1974; Mbugi et al. 1989). Similarly, digestibility of faba bean protein was reduced in young calves, although low levels of faba beans (up to about 0.15 of diet DM) could be used without adverse effects on growth rate (Wittenberg \& Ingalls, 1979; Ingalls et al. 1980).

We are not aware of any experimental studies which have examined incorporation of lupin protein into diets for young calves. On commercial farms lupin grain/barley mixtures are commonly fed to calves from about two weeks of age with satisfactory growth and without obvious detrimental effects (Dr G. Hough, personal communication).

Apparently none of the above grain legumes causes adverse effects such as the gut dysfunction and diarrhoea which may occur in preruminant calves fed diets containing soyabean meal. These have been attributed to morphological disturbances in the structure of small intestinal villi and an adverse immune reaction to antigenic globulins in the soyabean meal that remain even after processing (Barratt et al. 1979; Silva et al. 1986; Sissons et al. 1989). 
Table 8. Effects of various supplements including lupin grain or of intravenous infusions of glucose, acetate or glucose + acetate on ovulation rate and lambing rates in Merino ewes

\begin{tabular}{|c|c|c|c|}
\hline Measurement & $n$ & $\begin{array}{l}\text { Ovulation rate/ } \\
\text { ewe joined }\end{array}$ & $\begin{array}{c}\text { Lambs born/ } \\
\text { ewe joined }\end{array}$ \\
\hline \multicolumn{4}{|l|}{ Experiment 1} \\
\hline Control (no supplement) & 40 & $1 \cdot 13^{\mathrm{a}}$ & $0 \cdot 92^{\mathrm{a}}$ \\
\hline+ lupin grain $(510 \mathrm{~g} / \mathrm{d})$ & 40 & $1.47^{\mathrm{b}}$ & $1 \cdot 13^{b}$ \\
\hline+ wheat grain + urea $/ \mathrm{S}(510 \mathrm{~g} / \mathrm{d})$ & 40 & $1.08^{\mathrm{a}}$ & $0.94^{\mathrm{a}}$ \\
\hline + lucerne hay $(510 \mathrm{~g} / \mathrm{d})$ & 40 & $1 \cdot 15^{\mathrm{a}}$ & $0 \cdot 91^{\mathrm{a}}$ \\
\hline \multicolumn{4}{|l|}{ Experiment 2} \\
\hline Control (no supplement) & 116 & $1 \cdot 32^{\mathrm{a}}$ & - \\
\hline + lupin grain $(750 \mathrm{~g} / \mathrm{d})$ & 53 & $1 \cdot 65^{\mathrm{b}}$ & - \\
\hline+ glucose infused $\mathrm{i} / \mathrm{v}$ & 56 & $1 \cdot 67^{k}$ & - \\
\hline+ acetate infused $\mathrm{i} / \mathrm{v}$ & 50 & $1.51^{\mathrm{b}}$ & - \\
\hline+ glucose + acetate $i / v$ & 43 & $1 \cdot 64^{\mathrm{b}}$ & - \\
\hline+ formaldehyde-treated casein & 53 & $1 \cdot 42^{a b}$ & - \\
\hline \multicolumn{4}{|l|}{ Experiment 3} \\
\hline Control (no supplement) & 40 & $1 \cdot 13^{a}$ & - \\
\hline + lupin grain $(500 \mathrm{~g} / \mathrm{d})$ & 38 & $1 \cdot 51^{b}$ & - \\
\hline + formaldehyde-treated casein $(160 \mathrm{~g} / \mathrm{d})$ & 40 & $1 \cdot 50^{\mathrm{b}}$ & - \\
\hline+ formaldehyde-treated gelatine $(160 \mathrm{~g} / \mathrm{d})$ & 40 & $1 \cdot 30^{\mathrm{ab}}$ & - \\
\hline
\end{tabular}

Experiment 1, Kenney et al. (1980), ewes fed for 4 weeks.

Experiment 2, Teleni et al. (1985), ewes fed lupins or formaldehyde-treated casein or infused intravenously for 9 days before oestrus.

Experiment 3, Nottle et al. (1987), ewes fed supplements for 10 days beginning on day 7 of the oestrous cycle.

a.b. Within each experiment, values in the same column with different superscript letters were different $(P<0.05)$.

\section{REPRODUCTION}

A large number of experiments with ewes grazing dry summer pasture in Mediterranean climatic regions have shown that lupin grain supplements fed before joining for periods as brief as a few days often resulted in a 'flushing' effect with substantial increases in ovulation rate and hence reproduction rate (Lindsay, 1976; Table 8). It appears that it was the intake of the lupin grain during the luteal phase 5-8 days before ovulation which was critical (Stewart \& Oldham, 1986). The effect occurred over a range of metabolizable energy intakes and ewe liveweights, but did not occur with supplements of lucerne hay or cereal grain fortified with non-protein nitrogen and inorganic sulphur. The high protein content of lupin grain led to the hypothesis that stimulation of ovulation rate was due to increased supply to and absorption of amino acids by the ewe. This hypothesis is supported by experiments where ovulation rate was increased as much by formaldehyde-treated casein as by lupin grain, but not by formaldehyde-treated gelatine where the protein would have been deficient in essential amino acids (Nottle et al. 1987). However in the experiments of Teleni et al. $(1984,1985)$ intravenous infusions of glucose, acetate, or combinations of glucose and acetate increased ovulation rate as much as lupin grain supplements, suggesting that the effect was due to the supply of energy-yielding substrates in the lupin grain. Also, in data drawn from a number of experiments, 0.63 of the variation in ovulation rate was associated with glucose entry rate (Rowe, 1986). Since additional absorbed amino acids will usually increase glucose entry rate, it is possible that the response to formaldehyde-treated casein observed by Nottle et al. (1987) was due to an increased supply of glucose precursors rather than a direct effect of absorbed amino acids. Recent experiments of Downing et al. (1990) and Waghorn \& Smith (1990) have demonstrated 
associations between concentrations and supply of branched chain amino acids and ovulation rate, suggesting another mechanism by which lupin grain may stimulate ovulation rate. In conclusion, while there appears to be little argument that short-term change in level of nutrition by means such as lupin grain supplements can increase ovulation rate, the mechanism is not clear. At least part of the reason may simply be that ewes can consume large amounts of lupin grain without digestive upsets and the need for an adaptation period, and thus increase metabolizable energy intake immediately when supplements are provided.

Lupin grain and cowpea supplements have been used to increase level of nutrition, testicular size and hence fertility of Merino rams, but the increases in testicular size were apparently no greater than with other supplements which provided equivalent amounts of metabolizable energy (Murray et al. 1990; Pomares, 1991).

\section{PRODUCTION RESPONSES WITH LESS COMMON GRAIN LEGUMES}

Information is available on production responses of ruminants to a number of grain legumes known to contain sufficiently high levels of antinutritional factors in their raw states to be unsatisfactory for simple-stomached animals without processing.

Phaseolus vulgaris seeds contain high concentrations of lectins and proteinase inhibitors. Paduano et al. (1990) compared whole unprocessed navy beans (Phaseolus vulgaris var. Actolac) and lupin grain as supplements for sheep fed low-quality roughage, and observed that, at $5 \mathrm{~g}$ supplement $/ \mathrm{kg} \mathrm{LW}$, total DM intake, LW gain and wool growth of the sheep were increased to a similar extent by the two grain legumes. Although higher levels of lupin grain supplements (10 and $20 \mathrm{~g} / \mathrm{kg} \mathrm{LW}$ ) further increased these variables, with similar amounts of Phaseolus beans, intake and wool growth did not change and LW gain was reduced. Hence these sheep apparently utilized Phaseolus beans efficiently when they comprised 0.16 of the diet DM, but there were detrimental effects at 0.32 or more of diet DM intake. In contrast to these results, Williams et al. (1984) observed that steers could not tolerate even 0.16 of Phaseolus vulgaris (var. Processor) DM in a concentrate diet. In a second experiment the same steers consumed diets containing $0 \cdot 12-0 \cdot 18$ Phaseolus vulgaris beans when some roughage was included in the diet, but LW gain was lower than for the control diets. The greater ability of the sheep used by Paduano et al. (1990) to tolerate Phaseolus vulgaris grain in the diet may have been associated with differences in lectin contents of the beans used in each experiment, proportions of roughage in the diets and differences in the proteolytic activity of rumen microbes (Nugent \& Mangan, 1981), and the extent of passage of unmodified bean lectins from the rumen. The lectin content of various cultivars of Phaseolus vulgaris is known to vary widely.

Lablab (Lablab purpureus) beans and jack beans (Canavalia ensiformis) also contain high levels of antinutritional factors (lectins, proteinase inhibitors, tannins, cyanogenetic glucosides, the non-structural amino acid canavanine) which make them unsuitable in their raw state for inclusion into diets for simple-stomached animals (Phadke \& Sohonie, 1962; Dixon et al. 1983; Lambourne \& Wood, 1985). Whole unprocessed (Garcia, 1990) or insect damage cull (Ismartoyo, 1989) lablab seed (var. Highworth) has been compared with whole lupin grain as a supplement for sheep or goats fed low quality roughage. Although there were no overt symptoms of toxicity, feed intake, LW gain and wool growth were lower for lablab beans than for the equivalent amounts of lupin grain. In contrast to these results, growth of lambs was not affected by replacement of ground lupin grain by ground lablab grain in concentrate diets where the grain legumes constituted approximately 0.3 of DM intake (B. Lodebo, F. Woldetsadick, J. H. G. Holmes and R. M. Dixon, unpublished 
results). Canavalia beans could cause death when large amounts were given directly into the rumen of fasted cattle (Shone, 1961). However, in a number of experiments when Canavalia beans replaced cottonseed meal or soyabean in diets for growing sheep or cattle at levels up to $0 \cdot 3$ of intake, growth rates were similar to or only slightly less than those observed with the control diets (Dixon et al. 1983; Vasquez et al. 1987). In other experiments where higher levels of Canavalia grain have been incorporated into supplements, the intake of the supplement was low and growth rate was reduced (Paredes \& Escobar, 1984; Paredes et al. 1987).

A number of other grain legumes known to contain antinutritional factors have given production responses equal to those with control diets. Cowpeas (var. Caloona) contain proteinase inhibitors and tannins (Ologhobo \& Fetuga, 1983), but when used as a supplement for low quality roughages, intake and LW gain were similar to equivalent levels of lupin grain (Paduano et al. 1990; Pomares, 1991). Cowpeas and lupin grain gave equal wool growths at 5 and $10 \mathrm{~g} / \mathrm{kg} \mathrm{LW}$ levels of supplementation, but wool growth was depressed when $20 \mathrm{~g} / \mathrm{kg} \mathrm{LW}$ cowpeas were fed (D. C. Paduano and R. M. Dixon, unpublished results). This may have been due to proteinase inhibitors escaping rumen fermentation and reducing the availability of sulphur amino acids. This hypothesis is supported by the observation that faecal nitrogen excretion was increased with the cowpea supplement. Untreated narbon beans (Vicia narbonensis) are not suitable for poultry or pig diets (Davis, 1986; Johnson \& Eason, 1990), although the antinutritional factors responsible for this have not been identified. When peas and narbon beans were compared as supplements for sheep fed roughage, no detrimental effects on feed intake, LW change or wool growth were observed; indeed LW gains were higher for narbon beans than for peas at the $10 \mathrm{~g} / \mathrm{kg} \mathrm{LW}$ level of supplementation (Jaques et al. 1992). Pigeon peas (Cajanus cajan) contain proteinase inhibitors and tannins which reduce growth performance of pigs and poultry (Visitpanich et al. 1985; Tangtaweewipat \& Elliott, 1989). Nevertheless pigeon peas could replace soyabean meal and constitute approximately half the intake of growing sheep without adverse effects (Cheva-Isarakul, 1991). Chickpeas (Cicer arietinum) have been incorporated at high levels into diets of growing and lactating cattle (Illg et al. 1987). LW gain and efficiency of feed conversion were increased when chickpeas comprised $0 \cdot 1$ or $0 \cdot 2$ of intake, but decreased when chickpeas comprised 0.3 of intake.

\section{CONCLUSIONS}

Grain legumes are feedstuffs of high protein and metabolizable energy content. They are usually readily accepted by sheep and cattle, and animals require little adaptation to avoid rumen acidosis and reduced intakes. Grain legumes are likely to be particularly useful as supplements for low quality feeds in feeding systems where low levels of management input make it difficult to ensure satisfactory adaptation of animals to cereal grain based supplements, where high levels of non-protein $\mathrm{N}$ in supplements are inappropriate, and where it is desirable to give high levels of supplementary feed without prolonged adaptation phases. In Australia a particular role for lupin grain, and one which utilizes these advantages, has been supplementation of ewes to increase reproductive efficiency. Another important use of lupin grain is for supplementation of lactating dairy cows where high levels can be used without decreasing milk fat content. Grain legumes also have application in production rations as safe and robust alternatives to other forms of rumen degradable protein and metabolizable energy.

Of the many grain legume species available, only a few have become important field crops. Development of the technology to utilize high yielding tropical and subtropical grain legume species, already widely known but little used or liked as human food, could have 
a major impact on ruminant production systems in such regions where low quality of much of the available feed is a major constraint to animal productivity.

The principal limitations to the more efficient use of established grain legume crops for increased animal performance appear to be the high proportion of the grain legume protein present as rumen degradable protein, and the low sulphur-containing amino acid content of the protein. Effective low cost means to increase the escape of grain legume protein from the rumen and hence the undegraded dietary protein content are needed. The next constraint for many productive purposes is the sulphur-containing amino acid content of the grain protein. Therefore in the short term, means are also needed to provide sulphurcontaining amino acid supplements which escape rumen fermentation. In the long term attention could be placed on genetic manipulations to increase the sulphur-containing amino acid content of the undegraded dietary protein component of grain legumes.

In the context of the tropics and the subtropics the most important priority appears to be to define more precisely the effects, if any, on various aspects of animal productivity of the antinutritional factors known to be present in many of the high yielding grain legumes. With the exception of Canavalia ensiformis, little information is available. Where the antinutritional factors are of practical importance, measures will need to be developed to neutralize them, or to reduce their levels or their effects on the animal by genetic manipulation.

In regions where high protein byproducts such as oilseed meals are readily available at acceptable cost, production of grain legumes specifically for ruminant animal feed is not likely to be economically viable, but in regions where there is a shortage of high protein feedstuffs they may often constitute a valuable alternative.

Many of the concepts developed in this review have arisen from an ongoing programme in our institute on the nutritional value of grain legumes. The authors wish to thank Professor A. R. Egan and Dr J. H. G. Holmes for their numerous contributions and discussions, the many postgraduate students who have worked in this programme, and the Australian funding agencies (particularly AWC, MRC, AIDAB and IDP) who made the programme possible.

\section{REFERENCES}

Addison, K. B., Cameron, D. G. \& Blight, G. W. (1984). Highworth lablab grain as a supplement for beef cattle on native pasture. Proceedings of the Australian Society of Animal Production 15, 227-230.

Aguilera, J. F., Bustos, M. \& Molina, E. (1992). The degradability of legume seed meals in the rumen: effect of heat treatment. Animal Feed Science and Technology 36, 101-112.

Aitchison, E. M., Murray, P. J. \& Rowe, J. B. (1986). Improving the nutritive value of round bales of oat straw by treatment with urea or by supplementation with lupins. Proceedings of the Australian Society of Animal Production 16, 123-126.

Aitchison, E. M., Rix, G. S. \& Rowe, J. B. (1988). The effect of urea treatment of straw and lupin supplementation on intake, liveweight changes and wool growth in sheep. Proceedings of the Australian Society of Animal Production 17, 134-137.

Allden, W. G. (1969). The summer nutrition of weaner sheep: the voluntary feed intake, body weight change, and wool production of sheep grazing the mature herbage of sown pasture in relation to the intake of dietary energy under a supplementary feeding regime. Australian Journal of Agricultural Research 20, 499-512.

Allden, W. G. \& Geytenbeek, P. E. $(1980 a)$. Evaluation of nine species of grain legumes for grazing sheep. Proceedings of the Australian Society of Animal Production 13, $249-252$.

Allden, W. G. \& Geytenbeek, P. E. (1980 b). Assessment of field bean stubbles and supplements for grazing cattle and sheep. Proceedings of the Australian Society of Animal Production 13, 281-284.

Allden, W. G. \& Geytenbeek, P. E. (1984). A comparison of the growth of beef cattle and sheep grazing mature grain legume crops. Proceedings of the Australian Society of Animal Production 15, 648.

Arnold, G. W. \& Wallace, S. R. (1977). The comparative nutritive value for weaner sheep of stubble and grain of pea, vetch and lupin crops. Australian Journal of Agricultural Research 28, 143-154.

Ashes, J. R., Mangan, J. L. \& Sidhu, G. S. (1984). Nutritional availability of amino acids from protein crosslinked to protect against degradation in the rumen. British Journal of Nutrition 52, 239-247. 
Australian Feeds Information Centre (1987). Australian Feed Composition Tables [H. T. Ostrowski-Meissner, editor]. Sydney: AFIC-CSIRO.

Barratt, M. E. J., Strachan, P. J. \& Porter, P. (1979). Immunologically mediated nutritional disturbances associated with soya-protein antigens. Proceedings of the Nutrition Society 38, 143-150.

Barry, T. N., Manley, T. R.\& Duncan, S. J. (1986). The role of condensed tannins in the nutritional value of Lotus pedunculatus for sheep. 4. Sites of carbohydrate and protein digestion as influenced by dietary reactive tannin concentration. British Journal of Nutrition 55, 123-137.

Bartsch, B. D., Twigger, C. F. \& Valentine, S. C. (1986). Lupins, beans, peas and barley as alternative grains for dairy cows fed hay. Proceedings of the Australian Society of Animal Production 16, 404.

Batterham, E. S. \& Egan, A. R. (1986). Utilization of food legumes as feed. In Food Legume Improvement for Asian Farming Systems, pp. 193-200 [E. S. Wallis and D. E. Byth, editors]. Canberra: ACIAR.

Bell, J. M., Harvey, B. E. \& Christison, G. I. (1979). Effects of the addition of enzymes and carboxymethylcellulose to pea flour used for calf milk replacers. Canadian Journal of Animal Science 59, 43-50.

Bell, J. M., Royan, G. F.\& Youngs, C. G. (1974). Digestibility of pea protein concentrate and enzyme-treated pea flour in milk replacers for calves. Canadian Journal of Animal Science 54, 355-362.

Bhatty, R. S. \& Christison, G. I. (1980). Digestibility of pea proteins by pre-ruminant calves. Canadian Journal of Animal Science 60, 925-930.

Birk, Y. (1989). Protein protease inhibitors of plant origin and their significance in nutrition. In Recent Advances of Research in Antinutritional Factors in Legume Seeds, pp. 83-94 [J. Huisman, T. F. B. van der Poel and I. E. Liener, editors]. Wageningen: Pudoc.

Buckley, K. E., Devlin, T. J. \& Marquardt, R. R. (1983). Factors affecting in vitro rumen digestion of faba bean cultivars (Vicia faba L.). Canadian Journal of Animal Science 63, 89-96.

Butler, L. G. (1981). Supplementary feeding of Merino wethers grazing weed-free stubble pastures. Australian Journal of Experimental Agriculture and Animal Husbandry 21, 272-276.

Carbon, B. A., Arnold, G. W. \& Wallace, S. R. (1972). The contribution of lupin seed to the performance of animals grazing Uniwhite lupins. Proceedings of the Australian Society of Animal Production 9, $281-285$.

Castrillo, C., Lainez, M., Gasa, J. \& Guada, J. A. (1992). The effect of increasing the proportion of barley straw in pelleted concentrate diets given to lambs on rumen outflow rate and degradation of protein supplements. Animal Production 54, 59-66.

Cheeke, P. R. (1989). Pyrrolizidine alkaloid toxicity and metabolism in laboratory animals and livestock. In Toxicants of Plant Origin, vol. 1 Alkaloids, pp. 1-22 [P. R. Cheeke, editor]. Boca Raton, FL: CRC Press.

Cheva-Isarakul, B. (1991). Pigeon pea as ruminant feed. In Recent Advances in the Nutrition of Herbivores, p. 69 [M. W. Zahari, Z. A. Tajuddin, N. Abdullah and H. K. Wong, editors]. The Malaysian Society of Animal Production.

Cottle, D. J. (1988). Effects of defaunation of the rumen and supplementation with amino acids on the wool production of housed Saxon Merinos. 1. Lupins and extruded lupins. Australian Journal of Experimental Agriculture 28, 173-178.

Curtis, K. M. S. \& Mavrantonis, B. (1990). Intake of lupin seed and pasture by sheep fed lupins while grazing dry pasture. Proceedings of the Australian Society of Animal Production 18, 180-183.

Davies, R. L. (1986). Preliminary evaluation of narbon beans for pigs. In Grain Legumes for Low Rainfall Areas, pp. 39-41. Northfield Research Laboratory, Department of Agriculture of South Australia.

Davis, J. J., Bird, S. H. \& Leng, R. A. (1987). Lupins as a supplement for sheep. In Recent Advances in Animal Nutrition in Australia 1987, p. 5A [D. J. Farrell, editor]. Armidale, NSW: University of New England Publishing Unit.

Dixon, R. M., Escobar, A., Montilla, J., Viera, J., Carabaño, J., Mora, M., Risso, J., Parra, R. \& Preston, T. R. (1983). Canavalia ensiformis: a legume for the tropics. In Recent Advances in Animal Nutrition in Australia 1983, pp. 129-140 [D. J. Farrell and P. Vohra, editors]. Armidale, NSW: University of New England Publishing Unit.

Domingo, J. A. (1990). Anti-nutritional factors in legume seeds. Master of Agricultural Science thesis, University of Melbourne.

Downing, J. A., Scaramuzzi, R. J. \& Joss, J. (1990). Infusion of branched chain amino acids will increase ovulation rate in the ewe. Proceedings of the Australian Society of Animal Production 18, 472.

Edwards, D. G., Duthie, I. F., Rogers, B. M. \& Owen, E. (1973). A note on the digestibility by sheep of hulls from the field bean (Vicia faba L.). Animal Production 17, 329-332.

Egan, A. R., Frederick, F. \& Dixon, R. M. (1987). Improving efficiency of use of supplements by manipulation of management procedures. In Ruminant Feeding Systems Utilizing Fibrous Agricultural Residues-1986, pp. 69-81 [R. M. Dixon, editor]. Canberra: IDP.

Erickson, P. S. \& Barton, B. A. (1987). Whole soybeans for market lambs. Journal of Animal Science 64, 1249-1254.

Focant, M., Van Hoecke, A. \& Vanbelle, M. (1990). The effects of two heat treatments (steam flaking and extrusion) on the digestion of Pisum sativum in the stomachs of heifers. Animal Feed Science and Technology 28, 303-313.

Foot, J. Z., McIntyre, J. S. \& Heazlewood, P. G. (1983). Supplements for Merino weaner sheep grazing mature pastures in summer and autumn. Australian Journal of Experimental Agriculture and Animal Husbandry 23, $374-382$. 
Fortune, J. A., Hopkinson, W. S. \& Mackintosh, J. B. (1980). Formaldehyde treatment of lupin seed. Proceedings of the Australian Society of Animal Production 13, 474.

Fowden, L., Lewis, D. \& Tristram, H. (1967). Toxic amino acids: their action as antimetabolites. Advances in Enzymology 29, 89-163.

Freer, M. \& Dove, H. (1984). Rumen degradation of protein in sunflower meal, rapeseed meal and lupin seed placed in nylon bags. Animal Feed Science and Technology 11, 87-101.

Garcia, E. S. (1990). Lablab purpureus seed as a supplement for sheep fed roughage diets. Master of Agricultural Science thesis, University of Melbourne.

Godfrey, S. I., Murray, P. J. \& Rowe, J. B. (1990). Liveweight gain in Merino wethers fed twice weekly on a barley supplement treated with virginiamycin. Proceedings of the Australian Society of Animal Production 18, 480.

Griffiths, D. W. \& Jones, D. I. H. (1977). Cellulase inhibition by tannins in the testa of field beans (Vicia faba). Journal of the Science of Food and Agriculture 28, 983-989.

Hadsell, D. L. \& Sommerfeldt, J. L. (1988). Chickpeas as a protein and energy supplement for high producing dairy cows. Journal of Dairy Science 71, 762-772.

Hawthorne, W. A. (1980). Lupin grain as a supplement for grazing or penned steers. Proceedings of the Australian Society of Animal Production 13, 289-292.

Hill, G. D. (1977). The composition and nutritive value of lupin seed. Nutrition Abstracts and Reviews $B$ 47, $511-529$.

Hodge, R. W. \& Bogdanovic, B. (1983). Feeding hay supplemented with peas or low protein oats to crossbred lambs born in the spring. Australian Journal of Experimental Agriculture and Animal Husbandry 23, $19-23$.

Hodge, R. W., Bogdanovic, B. \& Sweatman, D. (1981). Wool production of Merino sheep fed daily or twice weekly on oats or lupins. Australian Journal of Experimental Agriculture and Animal Husbandry 21, $277-279$.

Hodge, R. W., Watson, M. J. \& Kat, C. (1984). Fermentation of wheat or lupins in the rumen of sheep. Canadian Journal of Animal Science 64, (Suppl.) 29-30.

Hosking, B. J. (1987). Evaluation of nutrient intake and digestion in grazing sheep receiving supplements. PhD thesis, University of Adelaide.

Hosking, B. J., James, H. B. \& Hynd, P. I. (1985). Oesophageal investigation of whole grain supplement ingestion. Proceedings of the Nutrition Society of Australia 10, 132.

Hough, G. M. (1991). Marketing Potential for Lupins in Dairy Cattle Production; Efficient Utilization of Lupins in Dairy Cattle Production; The Effect of Heat Treatment on the Feeding Value of Lupins. Bunbury, WA; WA Department of Agriculture, for Grain Research Council of Western Australia, Western Australian Cattle Industry Compensation Fund and Grain Legumes Research Council.

Huisman, J., van der Poel, T. F. B. \& Liener, I. E. [Editors] (1989). Recent Advances of Research in Anti-nutritional Factors in Legume Seeds: Wageningen: Pudoc.

Hume, I. D. (1974). The proportion of dietary protein escaping degradation in the rumen of sheep fed on various protein concentrates. Australian Journal of Agricultural Research 25, 155-165.

Hume, I. D. (1984). Evolution of herbivores - the rumen in perspective. In Ruminant Physiology-Concepts and Consequences, pp. 15-26[S. K. Baker, J. M. Gawthorne, J. B. Mackintosh and D. B. Purser, editors]. Nedlands, WA: University of Western Australia.

Hutson, G. D. \& Van Mourik, S. C. (1981). Food preferences of sheep. Australian Journal of Experimental Agriculture and Animal Husbandry 21, 575-582.

Hynd, P. 1. \& Allden, W. G. (1986). Lamb growth on grain legume crops and grains. Proceedings of the Australian Society of Animal Production 16, 29-31.

Hynd, P. I, Valentine, S. C. \& Bartsch, B. D. (1985). Rumen protozoa numbers in dairy cows fed barley or lupins. Proceedings of the Nutrition Society of Australia 10, 147.

Illg, D. J., Sommerfeldt, J. L. \& Boe, A. A. (1987). Chickpeas as a substitute for corn and soybean meal in growing heifer diets. Journal of Dairy Science 70, 2181-2185.

Ingalls, J. R. \& McKirdy, J. A. (1974). Faba beans as a substitute for soy bean meal or rapeseed meal in rations for lactating cows. Canadian Journal of Animal Science 54, 87-89.

Ingalls, J. R., McKirdy, J. A. \& Sharma, H. R. (1980). Nutritive value of faba beans in the diet of young Holstein calves and lactating dairy cows. Canadian Journal of Animal Science 60, 689698.

Ismartoyo (1989). Lablab purpureus seed as a supplement for goats fed roughage diets. Master of Agricultural Science thesis, University of Melbourne.

Jadhav, S. J., Reddy, N. R. \& Desphande, S. C. (1989). Polyphenols. In Handbook of World Food Legumes: Nutritional Chemistry, Processing Technology and Utilization, vol. 1, pp. 145-165 [D. K. Salunkhe and S. S. Kadam, editors]. Boca Raton, FL: CRC Press.

Jaffé, W. G. (1980). Hemagglutinins (lectins). In Toxic Constituents of Plant Foodstuffs, 2nd edn, pp. 73-102 [I. E: Liener, editor]. New York: Academic Press.

James, L. F., Allison, M. J. \& Littledike, E. T. (1975). Production and modification of toxic substances in the rumen. In Digestion and Metabolism in the Ruminant (International Symposium on Ruminant Physiology 4, 1974), pp. 576-590 [I. W. McDonald and A. C. I. Warner, editors]. Armidale, NSW: University of New England Publishing Unit.

Jaques, S., Dixon, R. M. \& Holmes, J. H. G. (1992). Narbon beans and field pea supplements for sheep fed pasture hay. Proceedings of the Australian Society of Animal Production 19, 249. 
Johnson, R. J. \& Eason, P. J. (1990). Effects of dietary inclusion of field peas, lupins, narbon beans and chickpeas on the growth performance of broiler chickens. In Australian Poultry Science Symposium 1990, pp. 96-99. Sydney, NSW: University of Sydney.

Jones, R. J. (1985). Leucaena toxicity and ruminal degradation of mimosine. In Plant Toxicology (Australia-U.S.A. Poisonous Plants Symposium, 1984), pp. 11I-119 [A. A. Seawright, M. P. Hegarty, L. F. James and R. F. Keeler, editors]. Brisbane, QD: Queensland Poisonous Plants Committee.

Kenney, P. A. (1981). Production by wethers fed oats, wheat and lupins with dry annual pasture in north-eastern Victoria. Australian Journal of Experimental Agriculture and Animal Husbandry 21, 480-484.

Kenney, P. A. (1986). Productivity of early-weaned lambs fed high-grain diets of wheat, oats or barley with or without lupin grain. Australian Journal of Experimental Agriculture 26, 279-284.

Kenney, P. A., Reeve, J. L., Baxter, R. W. \& Cumming, I. A. (1980). Effect of different levels of the supplements lupin grain, lucerne, wheat, and wheat with urea and sulphur fed during mating in February to Border Leicester $\times$ Merino ewes in north-east Victoria. Australian Joumal of Experimental Agriculture and Animal Husbandry 20, 15-19.

Kenney, P. A. \& Smith, R. S. (1985). Effects of including lupins with cereal grain rations on the production of lambing ewes during drought. Australian Journal of Experimental Agriculture 25, 529-535.

Lallès, J. P. \& Poncet, C. (1990). Changes in ruminal and intestinal digestion during and after weaning in dairy calves fed concentrate diets containing pea or soya bean meal. 1. Digestion of organic matter and nitrogen, Livestock Production Science 24, 129-142.

Lallès, J. P., Toullec, R., Patureau-Mirand, P. \& Poncet, C. (1990). Changes in ruminal and intestinal digestion during and after weaning in dairy calves fed concentrate diets containing pea or soya bean meal. 2. Amino acid composition and flow of duodenal and ileal digesta, and blood ievels of free amino acids. Livestock Production Science 24, 143-159.

Lambourne, L. J. \& Wood, I. M. (1985). Nutritional quality of grain of Australian cultivars of lablab bean (Lablab purpureus). Australian Journal of Experimental Agriculture 25, 169-177.

Lemerle, C., Etheridge, M. O. \& Trigg, T. E. (1985). Protein supplementation of dairy cattle on maize silage diets. Proceedings of the Nutrition Society of Australia 10, 158.

Liener, I. E. [Editor] (1980). Toxic Constituents of Plant Foodstuffs, 2nd edn. New York: Academic Press.

Liener, I. E. \& Kakade, M. L. (1980). Protease inhibitors. In Toxic Constituents of Plant Foodstuffs, 2nd edn, pp. $7-71$ [I. E. Liener, editor]. New York: Academic Press.

Lindsay, D. R. (1976). The usefulness to the animal producer of research findings in nutrition on reproduction. Proceedings of the Australian Society of Animal Production 11, 217-224.

Lindsay, J. R., Purser, D. B. \& Hogan, J. P. (1980). Supplementation of a low-quality roughage with lupin or cereal grains. Proceedings of the Australian Society of Animal Production 13, 479.

Lindsay, J. R., Purser, D. B. \& Hogan, J. P. (1982). Amino acid supply to the duodenum of sheep fed a low-quality roughage with a high-protein or high-energy supplement. Proceedings of the Nutrition Society of Australia 7 , 199.

McMeniman, N. P. \& Armstrong, D. G. (1979). The flow of amino acids into the small intestine of cattle when fed heated and unheated beans (Vicia faba). Journal of Agricultural Science 93, 181-188.

Mangan, J. L. (1988). Nutritional effects of tannins in animal feeds. Nutrition Research Reviews 1, $209-231$.

May, P. J. \& Barker, D. J. (1984). Milling barley and lupin grain in diets for cattle. Animal Feed Science and Technology 12, 57-64.

Mbugi, P. K., Ingalls, J. R. \& Sharma, H. R. (1989). Evaluation of pea protein concentrate as a source of protein in milk replacers for Holstein calves. Animal Feed Science and Technology 24, 267-274.

Miller, E. L. (1980). Protein value of feedstuffs for ruminants. In Vicia faba: Feeding Value, Processing and Viruses (Seminar, 1979), pp. 17-30 [D. A. Bond, editor]. The Hague: Martinus Nijhoff.

Moate, P. J., Rogers, G. L. \& Robinson, I. B. (1984). Lupins or oats as supplements for cows fed pasture in early lactation. Proceedings of the Australian Society of Animal Production 15, 721.

Mora, M., Parra, R., Combellas, J. \& Horesok, A. (1989). [Rumen function of sheep fed Canavalia ensiformis. 1. Detoxification of canavanine.] Informe Anual, Instituto de Producción Animal, Facultad de Agronomia, Universidad Central de Venezuela 1987, 55-56.

Mora, M., Parra, O., Escobar, A. \& Parra, R. (1980). [Effect of canavanine on the digestibility of cell wall of buffel grass (Cenchrus ciliaris)]. Informe Anual, Instituto de Producción Animal, Facultad de Agronomia, Universidad Central de Venezuela 1980, 30-31.

Mora, M., Risso, J., Escobar, A., Parra, R. \& Parra, O. (1981). [Results of studies on the toxicity of Canavalia ensiformis] Informe Anual, Instituto de Producción Animal, Facultad de Agronomia, Universidad Central de Venezuela 1981, 24-25.

Morcombe, P. W. \& Ferguson, J. (1990). Lupin, pea and wheat grain as supplements for young Merino sheep grazing wheat stubble. Proceedings of the Australian Society of Animal Production 18, 304-307.

Morcombe, P. W., Ralph, I. G. \& Ferguson, J. (1988). Frequency of feeding lupin grain supplements to lambing ewes grazing wheat stubble. Proceedings of the Australian Society of Animal Production 17, 262-265.

Murray, P. J., Rowe, J. B., Pethick, D. W. \& Adams, N. R. (1990). The effect of nutrition on testicular growth in the Merino ram. Australian Journal of Agricultural Research 41, 185-195.

Murray, P. J., Rowe, J. B. \& Speijers, E. J. (1991). Sulfur supplementation and the use of flavomycin with lupin grain for sheep. Austratian Journal of Agricultural Research 42, 1323-1333. 
National Academy of Sciences (1979). Tropical Legumes: Resources for the Future. Washington: National Research Council.

Newton, S. D. \& Hill, G. D. (1983). The composition and nutritive value of field beans. Nutrition Abstracts and Reviews B 53, 99-115.

Nottle, M. B., Setchell, B. P. \& Seamark, R. F. (1987). Protein, amino acids and ovulation rate in the ewe. Proceedings of the Nutrition Society of Australia 12, 88 .

Nugent, J. H. A. \& Mangan, J. L. (1981). Characteristics of the rumen proteolysis of fraction I (18S) leaf protein from lucerne (Medicago sativa L.). British Journal of Nutrition 46, 39-58.

Ologhobo, A. D. \& Fetuga, B. L. (1983). Investigation on the trypsin inhibitor, hacmagglutinin, phytic and tannic acid contents of cowpea (Vigna unguiculata). Food Chemistry 12, 249-254.

Orskov, E. R. \& McDonald, I. (1979). The estimation of protein degradability in the rumen from incubation measurements weighted according to rate of passage. Journal of Agricultural Science 92, 499-503.

Paduano, D. C., Slocombe, R. F., Holmes, J. H. G. \& Dixon, R. M. (1990). Cowpeas and navy beans as supplements for roughage diets for sheep. Proceedings of the Australian Society of Animal Production 18, 536.

Parades, L. \& Escobar, A. (1984). [Canavalia pods in rations for lactating cows at pasture.] Informe Anual, Instituto de Producción Animal, Facultad de Agronomía, Universidad Central de Venezuela 1983, 42-43.

Paredes, L., Escobar, A. \& Fernandez, L. (1987). [Effect of level of supplementation with Canavalia on growth of calves.] Informe Anual, Instituto de Producción Animal, Facultad de Agronomia, Universidad Central de Venezuela 1985-1986, 34-35.

Peter, D. W., Buscall, D. J. \& Young, P. (1987). Effects of sulphur and/or lupin supplements on the productivity of weaner sheep. In Herbivore Nutrition Research, pp. 203-304 [M. Rose, editor]. Australian Society of Animal Production, Occasional Publication.

Phadke, K. \& Sohonie, K. (1962). Nutritive value of field bean (Dolichos lablab). 2. Effect of feeding raw, autoclaved and germinated beans on the growth of rats and nitrogen balance studies. Journal of Scientific and Industrial Research 21C, 178-182.

Pomares, C. C. (1991). Lupin and cowpea supplements for production and reproduction in rams. Master of Agricultural Science thesis, University of Melbourne.

Puztai, A. (1989). Biological effects of dietary lectins. In Recent Advances of Research in Antinutritional Factors in Legume Seeds, pp, 17-29. [J. Huisman, T. F. B. van der Poel and I. E. Liener, editors]. Wageningen: Pudoc.

Reddy, N. R., Sathe, S. K. \& Salunkhe, D. K. (1989). Carbohydrates. In Handbook of World Food Legumes: Nutritional Chemistry, Processing Technology and Utilization, vol. 1, pp. 51-74 [D. K. Salunkhe and S. S. Kadam, editors]. Boca Raton, FL: CRC Press

Rowe, J. B. (1986). Association between glucose entry rate and ovulation rate in ewes. Proceedings of the Nutrition Society of Australia 11,91.

Rowe, J. B., Brown, G., Ralph, I. G., Ferguson, J. \& Wallace, J. F. (1989). Supplementary feeding of young Merino sheep, grazing wheat stubble, with different amounts of lupin, oat or barley grain. Australian Journal of Experimental Agriculture 29, 29-35.

Rowe, J. B. \& Ferguson, J. (1986). Lupin grain as a supplement to sheep grazing cereal stubble. Proceedings of the Australian Society of Animal Production 16, 343-346.

Rowe, J. B. \& Hargreave, G. T. (1988). Nutritive value of lupin hulls. Proceedings of the Australian Society of Animal Production 17, 463.

Salunkhe, D. K. \& Kadam, S. S. (1989a). Handbook of World Food Legumes: Nutritional Chemistry, Processing Technology and Utilization, vol. 1. Boca Raton, FL: CRC Press.

Salunkhe, D. K. \& Kadam, S. S. (1989 b). Handbook of World Food Legumes: Nutritional Chemistry, Processing Technology and Utilization, vol. 2. Boca Raton, FL: CRC Press.

Salunkhe, D. K. \& Kadam, S. S. $(1989$ c). Handbook of World Food Legumes: Nutritional Chemistry, Processing Technology and Utilization, vol. 3. Boca Raton, FL: CRC Press.

Sharma, H. R. \& Nicholson, J. W. G. (1975). Effects of treating faba beans with formaldehyde or volatile fatty acids on the performance of dairy calves and fistulated sheep. Canadian Journal of Animal Science 55, 705-713.

Shone, D. K. (1961). Toxicity of the jack bean. Rhodesia Agricultural Journal 58, $18-20$.

Silva, A. G., Huber, J. T., Herdt, T. H., Holland, R., Degregorio, R. M. \& Mullaney, T. P. (1986). Morphological alterations of small intestinal epithelium of calves caused by feeding soybean protein. Journal of Dairy Science 69, 1387-1393.

Sissons, J. W., Pedersen, H. E., Duvaux, C., Heppell, L. M. J. \& Turvey, A. (1989). Gut dysfunction and diarrhoea in calves fed antigenic soyabean protein. In Recent Advances of Research in Antinutritional Factors in Legume Seeds, pp. 359-362 [J. Huisman, T. F. B. van der Poel and I. E. Liener, editors]. Wageningen: Pudoc.

Smith, G. H. \& Warren, B. (1986a). Supplementation to improve the production of yearling steers grazing poor quality forage. 1. The effects of forage type and a cottonseed meal supplement. Australian Journal of Experimental Agriculture 26, 1-6.

Smith, G. H. \& Warren, B. (1986b). Supplementation to improve the production of yearling steers grazing poor quality forage. 2 . The effects of oats, supplementary nitrogen, Jupins and cottonseed meal. Australian Journal of Experimental Agriculture 26, 7-12.

Standing Committee on Agriculture (1990). Feeding Standards for Australian Livestock. Ruminants. Melbourne, Vict. : CSIRO. 
Stewart, R. \& Oldham, C. M. (1986). Feeding lupins to ewes for four days during the luteal phase can increase ovulation rate. Proceedings of the Australian Society of Animal Production 16, 367-370.

Tangtaweewipat, S. \& Elliott, R. (1989). Nutritional value of pigeon pea (Cajanus cajan) meal in poultry diets. Animal Feed Science and Technology 25, 123-135.

Teleni, E., King, W. R., Rowe, J. B. \& McDowell, G. H. (1989). Lupins and energy-yielding nutrients in ewes. 1. Glucose and acetate biokinetics and metabolic hormones in sheep fed a supplement of lupin grain. Australian Journal of Agricultural Research 40, 913-924.

Teleni, E., Rowe, J. B. \& Croker, K. P. (1984). Increased ovulation rates in ewes given intravenous infusions of energy-yielding substrates. Proceedings of the Nutrition Society of Australia 9, 158.

Teleni, E., Rowe, J. B., King, W. R., Murray, P. J. \& Croker, K. P. (1985). The effect of intravenous infusions of either glucose, acetate or glucose and acetate on ovulation rates in ewes. Proceedings of the Nutrition Society of Australia 10, 195.

Thompson, A. N. \& Curtis, K. M. S. (1990). The effects of lupin or oat grain supplements on liveweight change, staple strength and position of break for sheep grazing dry annual pastures. Proceedings of the Australian Society of Animal Production 18, 400-403.

Troccoli, N., Escobar, A. \& Fernandez, L. (1989). [Effect of ethanol on the toxicity of Canavalia ensiformis fed to calves before weaning.] Informe Anual, Instituto de Producción Animal, Facultad de Agronomia, Universidad Central de Venezuela 1987, 45-46.

Valentine, S. C. \& Bartsch, B. D. (1986). Digestibility of dry matter, nitrogen and energy by dairy cows fed whole or hammermilled lupin grain in oaten hay or oaten pasture based diets. Animal Feed Science and Technology 16, 143-149.

Valentine, S. C. \& Bartsch, B. D. (1987). Fermentation of hammermilled barley, lupin, pea and faba bean grain in the rumen of dairy cows. Animal Feed Science and Technology 16, 261-271.

Valentine, S. C. \& Bartsch, B. D. (1989). Milk production by dairy cows fed hammermilled lupin grain, hammermilled oaten grain or whole oaten grain as supplements to pasture. Australian Journal of Experimental Agriculture 29, 309-313.

Valentine, S. C. \& Bartsch, B. D. (1990). Milk production by dairy cows fed legume grains or barley grain with or without urea as supplements to a cereal hay based diet. Australian Journal of Experimental Agriculture 30 , $7-10$.

Valentine, S. C. \& Wickes, R. B. (1981). Nutritive value of alkali-treated wheaten straw fed to sheep with supplements of either lupins or barley and urea. Australian Journal of Experimental Agriculture and Animal Husbandry 21, 183-188.

Van Bruchem, J., Bongers, L. J. G. M., van Walsem, J. D., Onck, W. \& van Adrichem, P. W. M. (1985c). Digestion of proteins of varying degradability in sheep. 3. Apparent and true digestibility in the small intestine and ileal endogenous flow of $\mathrm{N}$ and amino acids. Netherlands Journal of Agricultural Science 33, $285-295$.

Van Bruchem, J., Rouwers, S. M. G., Bangma, G. A., Lammers-Wienhoven, S. C. W. \& van Adrichem, P. W. M. $(1985 \mathrm{~b})$. Digestion of proteins of varying degradability in sheep. 2. Amount and composition of the protein entering the small intestine. Netherlands Journal of Agricultural Science 33, 273-284.

Van Bruchem, J., Rouwers, S. M. G., Bangma, G. A., Leffering, C. P. \& van Adrichem, P. W. M. (1985a). Digestion of proteins of varying degradability in sheep. 1. Fermentation in and rate of passage from the reticulo rumen. Netherlands Journal of Agricultural Science 33, 263-272.

van der Poel, A. F. B. (1990). Effect of processing on the anti-nutritional factors and protein nutritional value of dry beans (Phaseolus vulgaris L.). A review, Animal Feed Science and Technology 29, 179-208.

Vasquez, W., Silva, E. J., Combellas, J. \& Escobar, A. (1987). [Evaluation of ground Canavalia grain and fishmeal as protein supplements in rations for weaned calves.] Informe Anual, Instituto de Producción Animal, Facultad de Agronomia, Universidad Central de Venezuela 1985-1986, 36-37.

Visitpanich, T., Batterham, E. S. \& Norton, B. W. (1985). Nutritional value of chickpea (Cicer arietinum) and pigeon pea (Cajanus cajan) meals for growing pigs and rats. 1. Energy content and protein quality. Australian Journal of Agricultural Research 36, 327-335.

Waghorn, G. C. \& Smith, J. F. (1990). The effect of protein and energy intake on physiological parameters and ovulation rate in ewes. Proceedings of the Australian Society of Animal Production 18, 563.

Watson, M. J., Hodge, R. W. \& Kat, C. (1984). Ruminal fermentation of wheat or lupins in sheep. Proceedings of the Nutrition Society of Australia $9,139$.

Williams, P. E. V., Pusztai, A. J., MacDiarmid, A. \& Innes, G. M. (1984). The use of kidney beans (Phaseolus vulgaris) as protein supplements in diets for young rapidly growing beef steers. Animal Feed Science and Technology 12, 1-10.

Wiseman, J. \& Cole, D. J. A. (1988). European legumes in diets for non-ruminants. In Recent Advances in Animal Nutrition-1988, pp. 13-37 [W. Haresign and D. J. A. Cole, editors]. London: Butterworths.

Wittenberg, K. M. \& Ingalls, J. R. (1979). Utilization of faba bean protein concentrate in milk substitute diets by pre-ruminant calves. Journal of Dairy Science 62, 1626-1631.

Woldetsadick, F., Dixon, R. M. \& Holmes, J. H. G. (1991). Absorption from the small intestine of sheep fed grain legumes. Proceedings of the Nutrition Society of Austratia 16, 210. 